\title{
Prevalence and Clinical Profiling of Dysglycemia and HIV infection in Persons with Pulmonary Tuberculosis in Brazil
}

1 María B. Arriaga ${ }^{1,2,3 a}$, Mariana Araújo-Pereira ${ }^{1,2,3 a}$, Beatriz Barreto-Duarte ${ }^{1,2,4,5 a}$, Caio Sales ${ }^{1,2,4}$, 2 João Pedro Miguez-Pinto ${ }^{1,2,4}$, Evelyn B. Nogueira ${ }^{1,2,4}$, Betânia M. F. Nogueira, ${ }^{1,2,3,6}$, Michael S. 3 Rocha ${ }^{1,2,6,7}$, Alexandra B. Souza ${ }^{8,9}$, Aline Benjamin ${ }^{10}$, Jamile G. de Oliveira ${ }^{11}$, Adriana S. R. 4 Moreira $^{12}$, Artur T. L. Queiroz ${ }^{2,13}$, Moreno M. S. Rodrigues ${ }^{14}$, Renata Spener-Gomes ${ }^{8,9,15}$, 5 Marina C. Figueiredo ${ }^{16}$, Betina Durovni ${ }^{11}$, Solange Cavalcante ${ }^{11}$, José R. Lapa-e-Silva ${ }^{5,12}$, 6 Afrânio L. Kristki ${ }^{5,12}$, Marcelo Cordeiro-Santos ${ }^{8,9,17}$, Timothy R. Sterling ${ }^{16}$, Valeria C. Rolla ${ }^{10}$, 7 Bruno B. Andrade ${ }^{1,2,3,4,7,16 *}$ and the RePORT-Brazil consortium ${ }^{\#}$

\#Additional authors from the RePORT Brazil consortium (corporate authorship): Alice M. S. Andrade $^{1,2}$, Juan M. Cubillos-Angulo ${ }^{1,2,3}$, Hayna Malta-Santos ${ }^{1,3}$, Jéssica Rebouças-Silva ${ }^{1,3}$, Saulo R. N. Santos ${ }^{6}$, André Ramos $^{6}$, Alysson G. Costa ${ }^{9,10}$, Jaquelane Silva ${ }^{9}$, Adriano Gomes-Silva ${ }^{16}$, Flávia M. Sant'Anna $^{16}$, Vanessa Nascimento ${ }^{2,6,7}$, Francine P. Ignácio ${ }^{16}$, Maria Cristina Lourenço ${ }^{18}$, Elisangela C. Silva $^{12}$, Mayla Mello ${ }^{12}$

${ }^{1}$ Laboratório de Inflamação e Biomarcadores, Instituto Gonçalo Moniz, Fundação Oswaldo Cruz, Salvador, Brazil

${ }^{2}$ Multinational Organization Network Sponsoring Translational and Epidemiological Research (MONSTER) Initiative, Salvador, Brazil

${ }^{3}$ Faculdade de Medicina, Universidade Federal da Bahia, Salvador, Brazil

${ }^{4}$ Escola de Medicina, Universidade Salvador (UNIFACS), Salvador, Brazil

${ }^{5}$ Programa de Pós-Graduação em Clínica Médica, Universidade Federal do Rio de Janeiro, Rio de Janeiro, Brazil

${ }^{6}$ Instituto Brasileiro para Investigação da Tuberculose, Fundação José Silveira, Salvador, Brazil

${ }^{7}$ Escola Bahiana de Medicina e Saúde Pública, Salvador, Brazil

${ }^{8}$ Fundação Medicina Tropical Doutor Heitor Vieira Dourado, Manaus, Brazil

${ }^{9}$ Programa de Pós-Graduação em Medicina Tropical, Universidade do Estado do Amazonas, Manaus, Brazil

${ }^{10}$ Laboratório de Pesquisa Clínica em Micobacteriose, Instituto Nacional de Infectologia Evandro Chagas, Fiocruz, Rio de Janeiro, Brazil

${ }^{11}$ Secretaria Municipal de Saúde do Rio de Janeiro, Rocinha, Rio de Janeiro, Brazil

${ }^{12}$ Programa Acadêmico de Tuberculose da Faculdade de Medicina, Universidade Federal do Rio de Janeiro, Rio de Janeiro, Brazil

${ }^{13}$ Center of Data and Knowledge Integration for Health, Instituto Gonçalo Moniz, Fundação Oswaldo Cruz, Salvador, Brazil

${ }^{14}$ Laboratório de Análise e Visualização de Dados, Fundação Oswaldo Cruz, Porto Velho, Brazil

${ }^{15}$ Universidade Federal do Amazonas, Manaus, Brazil

${ }^{16}$ Division of Infectious Diseases, Department of Medicine, Vanderbilt University School of Medicine, Nashville, Tennessee, USA

${ }^{17}$ Universidade Nilton Lins, Manaus, Brazil

* Correspondence: bruno.andrade@fiocruz.br

41 Keywords: Dysglycemia; HIV infection; pulmonary tuberculosis; Mycobacterium tuberculosis 


\section{Abstract}

43

44

45

46

47

48

49

50

51

52

53

54

55

56

57

58

59

60

61

62

63

64

65

66

Background: There are scarce data on the prevalence and disease presentation of HIV in patients with tuberculosis (TB) and dysglycemia (diabetes [DM] and prediabetes [PDM]), especially in TB-endemic countries. Methods: We assessed the baseline epidemiological and clinical characteristics of patients with culture-confirmed pulmonary $\mathrm{TB}$, enrolled in a multicenter prospective cohort in Brazil (RePORT-Brazil) during 2015-2019. Dysglycemia was defined by elevated glycated hemoglobin and stratified as PDM or DM. Additionally, we used data from TB cases obtained through the Brazilian National Notifiable Diseases Information System (SINAN), during 2015-2019. In SINAN, diagnosis of diabetes was based on self-report. Logistic regression models were performed to test independent associations between HIV, dysglycemia status, and other baseline characteristics in both cohorts. Results: In the RePORT-Brazil cohort, the prevalence of DM and of PDM was $23.7 \%$ and $37.8 \%$, respectively. Furthermore, the prevalence of HIV was $21.4 \%$ in the group of persons with TBdysglycemia and $20.5 \%$ in that of patients with TBDM. In the SINAN cohort, the prevalence of DM was 9.2\%, and among the TBDM group the prevalence of HIV was $4.1 \%$. Logistic regressions demonstrated that aging was independently associated with PDM or DM in both the RePORT-Brazil and SINAN cohorts. In RePORT-Brazil, illicit drug use was associated with PDM, whereas a higher body mass index (BMI) was associated with DM occurrence. Of note, HIV was not associated with an increased risk of PDM or DM in patients with pulmonary TB in both cohorts. Moreover, in both cohorts, the TBDM-HIV group presented with a lower proportion of positive sputum smear and a higher frequency of tobacco and alcohol users. Conclusion: There is a high prevalence of dysglycemia in patients with pulmonary TB in Brazil, regardless of the HIV status. This reinforces the idea that DM should be systematically screened in persons with TB. Presence of HIV does not substantially impact clinical presentation in persons with TBDM, although it is associated with more frequent use of recreational drugs and smear negative sputum samples during TB screening. 
medRxiv preprint doi: https://doi.org/10.1101/2021.10.29.21265663; this version posted October 30, 2021. The copyright holder for this preprint (which was not certified by peer review) is the author/funder, who has granted medRxiv a license to display the preprint in perpetuity.

It is made available under a CC-BY-NC-ND 4.0 nnternatipn tirense Pulmonary Tuberculosis

Approximately one-quarter of the world population is thought to be infected with Mycobacterium tuberculosis (Mtb) and about 5\%-10\% of those will develop active disease at some point in their lives, which represents a substantial public health problem (World Health Organization, 2021). Several factors are related to the development of active tuberculosis (TB), such as immunological, genetic, and metabolic factors. Importantly, metabolic disorders associated with glycemic status are considered important risk factors for the development active TB and also for unfavorable anti-TB treatment outcomes (Hensel et al., 2016). In addition, the immune deterioration caused by human immunodeficiency virus (HIV) favors the multiplication of Mtb and the progression to active TB (He et al., 2020).

Dysglycemia is a spectrum of metabolic dysfunctions related to glucose metabolism in the body, which includes several diseases, especially prediabetes (PDM) and diabetes (DM) (American Diabetes, 2021). Approximately 422 million people worldwide live with DM, most of whom are in low-and middle-income countries. Likewise, a significant part of the world's population suffers from PDM, an intermediate state of insulin resistance that partially affects the entry of glucose into cells (Abdul-Ghani et al., 2006; Goncalves et al., 2019). Interestingly, TB is similarly focused on low-and middle-income countries, which is a problem as DM triples the risk of developing active TB (Hayashi and Chandramohan, 2018). Furthermore, 15.3\% of people with TB worldwide have DM as a comorbidity (Noubiap et al., 2019). Persons with TB-DM usually exhibit a different clinical presentation, which includes higher frequency of extensive or cavitary pulmonary TB, a higher bacillary load in sputum and delayed mycobacterial clearance compared to normoglycemic TB patients (Singla et al., 2006; GilSantana et al., 2016). Although much has been described on the interaction between TB and DM in different settings, most of the studies investigated a limited number of participants, and larger studies are warranted to better define such interactions. In addition, the clinical outcomes as well as the pathophysiological mechanisms of patients with TB-DM are still poorly understood (Jeon and Murray, 2008; Hayashi and Chandramohan, 2018).

In addition to the importance of metabolic disorders, conditions that directly affect the immune response against $\mathrm{TB}$ are also a relevant problem as they contribute to more severe manifestations (World Health Organization, 2020). Importantly, people living with HIV (PLWH) are approximately 50 times more likely to develop active TB than those without HIV exposure (World Health Organization, 2020). Moreover, in 2019, PLWH accounted for 1.2 million (8.2\%) of the approximately 10 million people with TB worldwide and of those, 208,000 deaths were related to HIV comorbidity (World Health Organization, 2020). On the other hand, persons living with both TB and HIV often experience accelerated HIV disease progression and TB is placed as the most common opportunistic infection inducing high morbidity (World Health Organization, 2020). HIV has been shown to modify the course of TB by causing severe immunosuppression and Mtb dissemination to multiple organs and increased mortality (Geldmacher et al., 2010; Moir et al., 2011).

104 Brazil has a high burden of TB-DM (Noubiap et al., 2019) and TB-HIV (World Health Organization, 105 2021). Despite of the high of these comorbidities, to our knowledge there is no information that 106 explores in detail the association between HIV and TB-DM and its impact on clinical presentation of affected persons in the country. The scarce information that exists come from studies performed in African populations and with results that are not consistent with each other (Bailey and Ayles, 2017; Oni et al., 2017). Because of the abovementioned reasons, studies that examine the overlap of 110 metabolic and immunological diseases associated with TB are needed to better understand the spectrum 111 of disease presentation of patients with multiple comorbidities such as TB-DM-HIV. In the present 
112 study, we aimed at contributing to fill this gap in knowledge in the context of TB, dysglycemia, and

113 HIV-infection, through the identification and characterization of HIV prevalence and its association

114 with glycemic status among persons with active pulmonary TB, in the Regional Prospective

115 Observational Research in Tuberculosis (RePORT-Brazil) study, which is a large multicenter

116 prospective cohort of culture-confirmed pulmonary TB persons which has been shown to be

117 representative of the TB cases reported in the Brazilian national TB registry (Hamilton et al.,

118 2015;Arriaga et al., 2021). We also investigated such associations in TB cases reported to the Brazilian

119 National TB Registry through the National System of Diseases Notification (SINAN).

\section{METHODS}

\section{$122 \quad 2.1 \quad$ Ethics Statement}

123 All clinical investigations were conducted according to the principles of the Declaration of Helsinki.

124 The RePORT-Brazil protocol, informed consent, and study documents were approved by the 125 institutional review boards at each study site and at Vanderbilt University Medical Center (CAAE:

126 25102414.3.2009.5543). Participation in RePORT-Brazil was voluntary, and written informed consent

127 was obtained from all such participants.

\subsection{Study design - RePORT-Brazil}

This was a multicenter prospective observational cohort study of individuals $\geq 18$ years old with culture-confirmed pulmonary TB. RePORT-Brazil study sites are located in Manaus (Amazonas state, Northern region), Salvador (Bahia state, Northeastern region), and Rio de Janeiro (Rio de Janeiro state, Southeastern region), with a total of five health units: Instituto Nacional de Infectologia Evandro Chagas, Clínica da Família Rinaldo Delamare, and Secretaria Municipal de Saúde de Duque de Caxias (Rio de Janeiro), Instituto Brasileiro para Investigação da Tuberculose, Fundação José Silveira (Bahia), and Fundação de Medicina Tropical Doutor Heitor Vieira Dourado (Amazonas), representing both a heterogeneous population and the Brazilian cities with highest TB burden (Hamilton et al., 2015;Arriaga et al., 2021).

\subsection{Data collection - RePORT-Brazil}

139 Between 2015 and 2019, TB cases were interviewed for sociodemographic, clinical and epidemiological data such as age, sex, race/ethnicity (self-reported), body mass index (BMI), income, smoking status, passive smoking status (living with someone who smokes), alcohol and illicit drug use, and clinical data such as presence of TB symptoms (cough, fever, weight loss, fatigue, night sweats, chest pain) and had the following tests performed: chest X-ray, HIV serologic test (the test was not performed if the individuals had a previous diagnosis of HIV), CD4 and viral load (if HIV serology was positive or previous diagnosis of HIV-infection), complete blood count, glycated hemoglobin (HbA1c), sputum smear microscopy, Xpert-MTB-RIF (if available) and mycobacterial culture (Lowenstein-Jensen medium or BD BACTEC MGIT). Patients who received TB treatment or fluoroquinolones for $>7$ days in the 30 days prior to TB diagnosis and pregnant women were excluded. We only analyzed information collected at the study baseline. 
medRxiv preprint doi: https://doi.org/10.1101/2021.10.29.21265663; this version posted October 30, 2021. The copyright holder for this preprint (which was not certified by peer review) is the author/funder, who has granted medRxiv a license to display the preprint in perpetuity.

It is made available under a CC-BY-NC-ND 4.0 internatipnaltirense Pulmonary Tuberculosis

\subsection{Notifiable diseases information system (SINAN), Brazilian Ministry of Health}

153 SINAN is a system for the notification of transmissible diseases, including TB, that has been implemented, supported, and maintained by the Brazilian Ministry of Health (Ministério da Saúde do Brasil and Secretaria de Vigilância em Saúde, 2020). Data were collected from TB patients $\geq 18$ years old with information about "diabetes status", between 2015 and 2019. Persons who were homeless, prisoners, pregnant, or had extrapulmonary TB were excluded, resulting in a population of 279,143 individuals. TB was diagnosed according to the Brazilian Ministry of Health criteria, detailed in the Manual of Recommendations for the TB Control in Brazil (Ministério da Saúde do Brasil and Secretaria de Vigilância em Saúde, 2013). After TB diagnosis, the information collected at the baseline and the laboratory results were recorded on a standardized form that, individual characteristics (sex, age, race, education level, alcohol consumption, illicit drug use, smoking habits, and comorbidities), the presence of DM condition ("yes" or "no" options) and HIV-infection, among others (Ministério da Saúde do Brasil and Secretaria de Vigilância em Saúde, 2013).

\subsection{Study definitions}

In pulmonary $\mathrm{TB}$ cases from RePORT-Brazil, participants with HbA1c $\geq 5.7 \%$ were classified as dysglycemic and those with $\mathrm{HbA} 1 \mathrm{c}<5.7 \%$ were considered normoglycemic. Study participants were also classified as having DM (HbA1c $\geq 6.5 \%)$, PDM (HbA1c $=5.7-6.4 \%)$ or normoglycemia $(\mathrm{HbA} 1 \mathrm{c}<$ $5.7 \%$ ), following American Diabetes Association (ADA) guidelines (International Diabetes

170 Federation, 2019).

\subsection{Data analysis}

Categorical variables were presented as proportions and compared using a two-sided Pearson's chisquare test (with Yates's correction) or Fisher's two-tailed test in $2 \times 3$ or $2 \times 2$ tables, respectively. Continuous variables were presented as median and interquartile range (IQR) and compared using the Mann Whitney $U$ (between 2 groups) or Kruskal Wallis test (between $\geq 2$ groups). Viral load values and CD4 count were transformed to $\log 10$ for analyses. Multinomial and binomial logistic regression models with stepwise method (Wald) were performed to evaluate independent associations between clinical characteristics of pulmonary TB cases and presence of diabetes and/or prediabetes in the Report-Brazil and SINAN cohorts. Parameters with $p$-values $\leq 0.2$ in univariate analyses were included in multivariable models. P-values $<0.05$ were considered statistically significant. All the analyses were pre-specified. Statistical analyses were performed using SPSS 24.0 (IBM statistics), Graphpad Prism 9.0 (GraphPad Software, San Diego, CA) and R 3.1.0 (R Foundation, Austria).

\section{$183 \quad 3 \quad$ RESULTS}

\subsection{Characteristics of the study participants}

185 RePORT-Brazil enrolled 1,162 patients with culture-positive pulmonary TB during 2015-2019 from 186 the five centers of the consortium. The prevalence of dysglycemia at TB diagnosis was $61.5 \%$ (95\% CI: 18758.6 - 64.2). Compared to normoglycemic individuals, those with dysglycemia were more likely male $(68.8 \%$ vs 61.8\%, $\mathrm{p}=0.018)$ and older (39, IQR:29-52 years, $\mathrm{p}<0.001)$. Among TB-DM cases, 122/275 $(44.4 \%)$ had previous diagnosis of DM. The dysglycemia group also exhibited higher frequency of self-reported pardo race $(\mathrm{n}=388,54.4 \%, \mathrm{p}=0.007)$, a higher median of BMI value (20.5, IQR:18.4- 
medRxiv preprint doi: https://doi.org/10.1101/2021.10.29.21265663; this version posted October 30, 2021. The copyright holder for this preprint (which was not certified by peer review) is the author/funder, who has granted medRxiv a license to display the preprint in perpetuity.

It is made available under a CC-BY-NC-ND 4.0 internatipnaltirense Pulmonary Tuberculosis

191

192

193

194

195

196

197

198

199

200

201

202

203

204

205

206

207

208

209

210

211

212

213

214

215

216

217

218

219

220

221

222

223

224

225

226

227

228

229

230

231

232

233

$23.1 ; \mathrm{p}<0.001)$ and a higher frequency of self-reported weight loss $(\mathrm{n}=597,93 \% ; \mathrm{p}=0.016)$ but not of other TB symptoms (Table 1).

\subsection{Characteristics of TB cases by glycemic status}

In RePORT-Brazil, the DM and PDM prevalence at TB diagnosis was $23.7 \%$ (95\%CI: $21.31-26.2 \%)$ $(\mathrm{n}=275)$, and $37.8 \%(95 \% \mathrm{CI}: 35.0 \%-40.6 \%)(\mathrm{n}=439)$, respectively (Figure 1A). Several clinical characteristics differed between normoglycemic and dysglycemic TB patients, with significant differences in frequency of sex $(p=0.027)$, age $(p<0.001)$ race/ethnicity $(p<0.001)$, BMI values $(\mathrm{p}<0.001)$ and the frequency of self-reported weight loss as a symptom $(\mathrm{p}=0.033)$ between the three groups (Table 2).

To evaluate these differences in more detail, we performed pair-wise comparisons between the groups. The highest median age was observed in the DM group (46 years; IQR: 36-55), which was significantly higher than PDM (36, IQR: 26-47) and normoglycemia (31, IQR: 23-42). We also observed differences between PDM and normoglycemia, with $\mathrm{p}<0.001$ in both comparisons (Figure 1B). In addition, the DM group had higher median BMI (21.6, IQR: 19.1 - 24.4) than PDM (19.9, IQR: 18.4 - 21.80, $\mathrm{p}<0.001)$ and normoglycemia (19.8, IQR: $17.9-22.0, \mathrm{p}<0.001)$, but there was no difference between PDM and normoglycemic individuals $(\mathrm{p}=0.53$ ) (Figure 1B). TB patients with DM more frequently presented with positive smear $(p=0.037)$, weight loss $(p=0.027)$ and cough $(p=0.038)$ than those with normoglycemia (Figure 1C). Patients with PDM similarly exhibited higher frequency of weight loss $(\mathrm{p}=0.027)$ compared with persons with normoglycemia at baseline (Figure 1C). Of note, $44.4 \%$ $(\mathrm{n}=122)$ of the participants with DM already knew about their diagnosis of DM before being enrolled in the study (Figure 1D, Table 2).

To assess whether the results obtained from the analyses of the RePORT-Brazil cohort mirrored the data from the overall Brazilian TB population, we characterized the TBDM cases reported to the SINAN registry (Figure 2). Of 279,143 pulmonary TB cases reported between 2015 and 2019, 25,765 had DM (self-reported), resulting in a prevalence of 9.2\% (95\%CI: 9.1\%-9.3\%) (Table 3, Figure 2A). Patients with TB-DM were older (55 years, IQR:46-64) than normoglycemic patients (40 years, IQR:29-54; $\mathrm{p}<0.001)$ (Figure 2B), had a higher frequency of abnormal chest $\mathrm{X}$-ray $(\mathrm{p}<0.001)$, positive smear $(p<0.001)$, positive culture $(p<0.001)$ and were new cases more frequently reported $(p<0.001)$ than in normoglycemic patients (Figure 2C, Table 3). In contrast, normoglycemic persons were more frequently men $(p<0.001)$, reported greater consumption of alcohol $(\mathrm{p}<0.001)$ and illegal drug use $(p<0.001)$ and more frequent tobacco use $(p<0.001)$ than those with DM. Finally, normoglycemic TB patients were mainly black/pardo $(\mathrm{p}<0.001)$ and more frequently had drug-sensitive TB than TB-DM participants $(\mathrm{p}<0.001)$ (Table 3).

\subsection{Characteristics of HIV status among TB cases with dysglycemia}

In RePORT-Brazil, the association between HIV-infection status and dysglycemia at baseline in participants with active pulmonary TB was analyzed according to age, presence of DM or PDM as well as to HbAlc levels (Figure 3). Importantly, the distribution of $\mathrm{HbAlc}$ values among persons with $\mathrm{TB}$ did not differ significantly according to HIV-infection status (Figure 3A, left panel). In fact, HIVinfection was present in the minority of the active TB cases in all sub-categories of glycemic status. The HIV-infection prevalence in the TB-dysglycemia group was 21.4\% (95\%CI: 18.6\%-4.3\%) (Figure 3A, right panel). There was a significant difference in the frequency of TB patients with either DM $(p<0.001)$ or HIV-infection $(\mathbf{p}<0.001)$ according to age category (Figure 3B), whereas there was no significant difference in the distribution of PDM among the different age categories $(\mathrm{p}=0.099)$. (Figure 
medRxiv preprint doi: https://doi.org/10.1101/2021.10.29.21265663; this version posted October 30, 2021. The copyright holder for this preprint (which was not certified by peer review) is the author/funder, who has granted medRxiv a license to display the preprint in perpetuity.

It is made available under a CC-BY-NC-ND 4.0 internatipnaltivense Pulmonary Tuberculosis

234 3B). Of note, the subgroup of older participants ( $>48$ years-old) exhibited the highest frequency of DM 235 (Figure 3B).

236 Further comparisons revealed no differences in the distribution of HbA1c values between PLWH undertaking antiretroviral therapy (ART) and those who were ART-naïve at the time of study enrollment (Figure 3C). There was a non-significant positive correlation between HbA1c levels and HIV viral load (Figure 3D, left panel) and also between HbA1c concentrations and CD4 T-cell counts (Figure 3D, right panel) when all PLWH were considered regardless of the glycemic status (Figure 3D, left panel). In contrast, in the SINAN cohort, we found a prevalence of HIV-infection in the DM sub-group of 4.1\% (95\% CI: 3.8\%-4.3\%) (Figure E), lower than what was observed in the RePORTBrazil cohort. Moreover, older TB patients (age $>48$ years) were more frequently found in in the DM and HIV-infection subgroups $(\mathrm{p}<0.001)$ than other age groups (Figure $\mathbf{F})$.

\subsection{Factors associated with dysglycemia in patients with active pulmonary TB}

Multinomial logistic regression analyses were performed to test associations between characteristics of active pulmonary TB patients and the presence of PDM or DM in RePORT-Brazil participants. Results demonstrated that increases in age (per 1-year increase) were independently associated with an increased odds of PDM (adjusted odds ratio [aOR]: 1.02, IQR:1.01-1.03, p<0.001) or DM (aOR:1.06, IQR:1.04-1.07, $\mathrm{p}<0.001)$. Furthermore, self-reported illicit drug use (aOR:1.74, IQR:1.23-2.45, $\mathrm{p}=0.002$ ) was related to increased odds of PDM but not DM. Higher BMI values (per $1 \mathrm{Kg} / \mathrm{m}^{2}$ increase; aOR:1.09, IQR:1.05-1.14, p<0.001) and presence of positive smear at baseline (aOR:1.61, IQR:1.08$2.40, \mathrm{p}<0.001$ ) were both independently associated with increased odds of DM but not PDM. Of note, no association was found between presence of HIV-infection and odds of presenting with PDM $(p=0.956)$ or DM $(p=0.174)$ in the RePORT-Brazil cohort (Figure 4A).

256

257

To test associations between characteristics of TB and the presence of DM in the SINAN cohort, a binomial logistic regression analysis was performed. In this cohort, aging (per 1-year increase; aOR: 1.04, IQR:1.04-1.05, $\mathrm{p}<0.001$ ), positive smear (aOR: 1.26, IQR:1.13-1.39, $\mathrm{p}<0.001$ ) and abnormal chest X-ray $(\mathrm{aOR}: 1.56$, IQR:1.49-1.63, $\mathrm{p}<0.001)$ at baseline were independently associated with presence of DM. In contrast, male sex (aOR: 0.77, IQR:0.73-0.80, $\mathrm{p}<0.001$ ), current smoking (aOR: 0.93, IQR:0.89-0.98, p <0.001), alcohol consumption (aOR: 0.92, IQR:0.87-0.97, p <0.001), use of illicit drugs (aOR: 0.72, IQR:0.66-0.79, p<0.001) and to live with HIV (aOR: 0.42, IQR:0.38-0.46, $\mathrm{p}<0.001$ ) were all associated with a decreased odds of DM (Figure 4B).

\subsection{Clinical and epidemiologic profiling according to the glycemic status and HIV}

In the RePORT-Brazil cohort, the TBDM-HIV, TBPDM-HIV and TB-HIV groups presented similar frequencies for male sex $(\approx 75.9 \%, \mathrm{p}=0.002)$. Interestingly, the highest median age was in the TBDM group (49 years), followed by 36 years in the TBDM-HIV and TBPDM groups, with the lowest median age observed in the TB group (30 years) $(\mathrm{p}<0.001)$ (Table 4). Pardo race was the most reported in the TBDM-HIV group (69.6\%). Drug resistance to isoniazid was more frequently observed in the groups with HIV coinfection $(p=0.036)$ (Table 4).

TB cases with HIV comorbidity displayed lower proportions of abnormal chest radiographs $(\mathrm{p}<0.001)$ and of smear-positive sputum samples $(\mathrm{p}<0.001)$ (Figure 5A, Table 4). We observed that tobacco use $(64.3 \%)$ and alcohol consumption $(94.6 \%)$ were significantly more reported in the TBDM-HIV group when compared to the clinical groups without HIV. (Figure 5B, Table 4). As expected, regarding to the TB classic symptoms, the participants from the TBDM-HIV group presented a lower frequency of 
medRxiv preprint doi: https://doi.org/10.1101/2021.10.29.21265663; this version posted October 30, 2021. The copyright holder for this preprint (which was not certified by peer review) is the author/funder, who has granted medRxiv a license to display the preprint in perpetuity. It is made available under a CC-BY-NC-ND 4.0 internatipnaltirense Pulmonary Tuberculosis

cough $(p=0.004)$ and a higher percentage of patients with weight loss $(p=0.018)($ Figure 5C, Table 4).

We found a similar clinical profile in the SINAN cohort, where the TBDM-HIV group was characterized by a higher frequency of male sex (70.1\%). Furthermore, the highest median age was 55 years among TBDM cases, followed by 49 years in the TBDMHIV group $(p<0.001)$ (Table 5). Such as in RePORT-Brazil, the pardo race was the most self-reported in all groups. Remarkably, the TBDMHIV group presented a slight proportion of drug resistance cases, and especially to rifampicin and isoniazid $(8.1 \%)(\mathrm{p}<0.001)$.

Similar to the abovementioned results on the RePORT-Brazil, in the SINAN cohort we found a low frequency of positive smear in the TBDM-HIV $(61.8 \%)$ and TB-HIV $(55 \%)$ groups $(\mathrm{p}<0.001)$ as well as of abnormal X-rays ( $89.1 \%$ and $87.9 \%$, respectively) $(p<0.001)$ (Figure 6A, Table 5). Furthermore, the positive culture results were also less frequently reported in the groups with HIV comorbidity when compared to the groups of individuals non-exposed to HIV ( $p<0.001$ ). (Figure 6B, Table 5). Finally, TBDM-HIV cases more frequently reported the tobacco smoking (27.9\%) and alcohol consumption $(28.4 \%)(\mathrm{p}<0.001)$ (Figure 6C, Table 5).

\section{DISCUSSION}

Characterizing the association between TB, dysglycemia and HIV is important to understand the influence of metabolic and immunologic dysregulation in the presentation of the TB disease. The TBDM association is frequent worldwide; currently, more TB patients live with DM than with HIV (Girardi et al., 2017). In the RePORT-Brazil cohort, the prevalence of dysglycemia among TB patients at baseline was $61.5 \%(37.8 \% \mathrm{PDM}$ and $23.7 \% \mathrm{DM})$. This prevalence was higher than that recently reported in Ghana (Yorke et al., 2021), Peru (Calderon et al., 2019) and in the South of Brazil (Beraldo et al., 2021). The RePORT-Brazil cohort is large and composed by individuals from different regions of Brazil, and we have recently shown that it is representative of Brazilian patients with TB (Arriaga et al., 2021). The present work reports findings consistent with the literature, where TB-dysglycemia (mainly DM) patients have increased BMI values and higher prevalence of weight loss than normoglycemic patients (Almeida-Junior et al., 2016). TB-DM patients in RePORT-Brazil exhibited similar characteristics to those in a large cohort of 709,000 Brazilians with TB from 2007 to 2014: mostly men, mean age $>40$ years and self-reported black or pardo (Evangelista et al., 2020).

TB patients more frequently reported smoking and use of illicit drugs and alcohol, which are shared risk factors not only for TB but also for DM (Yu et al., 2014;Pelissari and Diaz-Quijano, 2018). The multinomial regression analysis demonstrated that illicit drug use was associated with increased odds of PDM, whereas alcohol use and smoking were associated with DM in the unadjusted model. Also in this analysis, aging was associated with both PDM and DM, and higher BMI was associated with presence of DM. These are factors already described as risk factors for TB in patients with DM, in addition to a lack of glycemic control (Khalil and Ramadan, 2016) . The majority (55.6\%) of the TBDM patients in the RePORT-Brazil study had no previous diagnosis of dysglycemia, which can be related to a lack of glycemic control that may be contributing to a more severe symptomatology (Khalil and Ramadan, 2016), considering that coughing was a symptom associated with DM. The rate of newly diagnosed patients was high compared to other studies (Abdelbary et al., 2016), representing $66 \%$ of DM cases in RePORT Brazil cohort, demonstrating the importance of DM screening at the time of TB diagnosis. 
medRxiv preprint doi: https://doi.org/10.1101/2021.10.29.21265663; this version posted October 30, 2021. The copyright holder for this preprint (which was not certified by peer review) is the author/funder, who has granted medRxiv a license to display the preprint in perpetuity. It is made available under a CC-BY-NC-ND 4.0 internatipnaltirense Pulmonary Tuberculosis

319

320

321

322

323

324

325

326

327

328

329

330

331

332

333

334

335

336

337

338

339

340

341

342

343

344

345

346

347

348

349

350

351

352

353

354

355

356

357

358

359

360

361

362

363

364

Using data from SINAN, we observed that between 2015 and 2019, the frequency of TB-DM in Brazil was only $9.2 \%$, lower than the global prevalence of $15 \%$ and higher than the South American prevalence of $7.7 \%$, calculated from a meta-analysis of more than 200 studies recently conducted around the world (Noubiap et al., 2019). When comparing our original data with the results obtained through SINAN, in RePORT-Brazil, patients with TB-DM were more likely to be male, black/pardo, older and more frequently to have a positive sputum smear than persons without DM, reinforcing the idea that the results obtained with RePORT-Brazil are representative of the country's population. However, in contrast to RePORT-Brazil, in SINAN, TB-DM patients had a significantly lower frequency of HIV-infection than those who did not report DM. This difference found in SINAN may be since glycemic control is performed in all the study participants diagnosed with dysglycemia, whereas it is only recommended, and not mandatory, in the national guidelines. In addition, there is a potential underreporting of cases in SINAN, and only DM cases, but not PDM, are notified. We have discussed this limitation in the SINAN database previously (Arriaga et al., 2021), where the performance of health and epidemiological indicators was substantially higher in RePORT-Brazil than in the cases notified to SINAN. In the SINAN cohort, there was a lower proportion of males in the TBDM group, probably due to the higher percentage of women diagnosed with diabetes (Abreu et al., 2020). On the other hand, the lower frequency of alcohol, smoking and illicit drug use could be attributed to the fact that this information is self-reported by patients rather than formally investigated (Santos et al., 2018).

In RePORT-Brazil, most patients with DM or PDM were HIV-seronegative. Other studies had shown this low frequency of HIV-infection in association with DM in Brazil (Almeida-Junior et al., 2016; Evangelista et al., 2020). HbAlc levels were also similar in TB patients stratified by HIV status. There is scarce evidence describing the interaction of HbAlc values and HIV in patients with TB. One study described that HbAlc could underestimate real glycemia values in PWLH (Glesby et al., 2010). Furthermore, dysglycemia risk in PLWH has been shown to be increased after initiating ART (Julius et al., 2011), which could be a potential confounding factor, but HIV-infection was not associated with occurrence of dysglycemia in our study in both cohorts, even when stratified by age. Of note, in the SINAN cohort, presence of HIV-infection was linked to increased likelihood of normoglycemia in the population with pulmonary TB. Thus, the findings presented here from both large cohorts analyzed in this study argue that HIV-infection does not appear to be a determinant of dysglycemia in patients with pulmonary TB in Brazil.

To investigate whether HIV had any influence on dysglycemia in the RePORT-Brazil cohort, we tested for correlations between HbAlc and HIV-1 viral load or CD4 T-cell counts. We found just weak and non-significant correlations, indicating that HIV progression may not influence the occurrence of significant hyperglycemia. A study in PLWH that used fasting plasma glucose to measure glycemia reported that CD4 T-cell counts, and HIV viral load could influence blood glucose levels (Duro et al., 2015). Further studies are necessary to clarify whether HIV disease progression affects glycemic control by measuring several laboratory parameters simultaneously, such as HbAlc, fasting glucose levels or oral glucose tolerance tests. Our findings clearly corroborate the idea that despite the effect of HIV-infection on the immune system, glucose metabolism does not seem to be highly affected by this infection or disease progression.

We show the groups according to the glycemic status and by HIV infection and we identified that the group of persons with TBDM-HIV present with some peculiar characteristics. Male sex, smoking and alcohol consumption were higher in the TBDM-HIV group. We did not find specific literature to be able to contrast to our results. However, a study in 132 people with HIV described that the male population has a strong association with smoking, and in turn there is a strong interaction between 
medRxiv preprint doi: https://doi.org/10.1101/2021.10.29.21265663; this version posted October 30, 2021. The copyright holder for this preprint (which was not certified by peer review) is the author/funder, who has granted medRxiv a license to display the preprint in perpetuity. It is made available under a CC-BY-NC-ND 4.0 internatipnaltirense Pulmonary Tuberculosis

365

366

367

368

369

370

371

372

373

374

375

376

377

378

379

380

381

382

383

384

385

386

387

388

389

390 smoking and alcohol consumption in infected men with HIV (Bhatta et al., 2018) which is consistent with the results of our study. Immunodeficiency and a decreased inflammatory response can inhibit sputum production in individuals with HIV; such cases also tend to have fewer atypical findings on radiographs (Abaye et al., 2017), which coincides with the overall low percentage of cough and lower frequency of abnormal x-rays found in the TBDM-HIV, TBPDM-HIV and TB-HIV groups. Among the groups of individuals living with HIV, the TBDM-HIV presented a higher proportion of abnormal $\mathrm{X}$-rays and self-reported cough. We hypothesize that presence of DM may boost immunopathological mechanisms that lead to tissue damage and inflammation which results in abnormal radiographs and cough. Reinforcing this idea, we have previously reported that the transcriptome of TB-DM patients exhibits increased representation of neutrophilic inflammation pathways (Prada-Medina et al., 2017), which may contribute at least in part to lung damage leading to cough and altered x-rays.

The present study has some limitations. In RePORT-Brazil, dysglycemia was investigated by means of HbA1c levels; we did not perform fasting glucose levels or oral glucose tolerance tests. Although glycated hemoglobin levels have been reliably used to estimate dysglycemia in several studies, it is possible that the final numbers of DM and PDM would have differed if additional laboratory assessments had been used. In addition, the use of anti-DM drugs was not uniformly recorded. In SINAN, diabetes condition is notified without differentiating if it was self-reported or if it had a laboratory confirmation. Therefore, the accuracy of DM diagnosis may have been affected. Regardless of its limitations, the present study adds important knowledge to the study of dysglycemia in TB patients in a large well-characterized multicenter cohort from Brazil, enabling the identification of factors associated with PDM and DM in this population. We also demonstrate that the majority of patients with TB-DM had no previous diagnosis of dysglycemia, which may be associated with an underreporting of DM in the SINAN database, and that HIV-infection was not significantly associated with dysglycemia in TB patients. It is important to systematically screen for DM in TB patients and initiate appropriate therapy for both diseases to reduce the dual burden of these major diseases. 
3925 Tables

393 Table 1. Characteristics of TB cases by glycemic status in RePORT-Brazil cohort

\begin{tabular}{|c|c|c|c|}
\hline Characteristics & $\begin{array}{c}\text { Dysglycemia } \\
(n=714)\end{array}$ & $\begin{array}{l}\text { Normoglycemia } \\
\quad(n=558)\end{array}$ & p-value \\
\hline Male sex - no. (\%) & $491(68.8)$ & $277(61.8)$ & 0.018 \\
\hline Age - median (IQR) & $39(29-52)$ & $31(23-42)$ & $<0.001$ \\
\hline HIV infection - no. (\%) & $153(21.5)$ & $91(20.7)$ & 0.798 \\
\hline Race/Ethnicity - no. (\%) & & & 0.007 \\
\hline White & $135(18.9)$ & $107(23.9)$ & \\
\hline Black & $174(24.4)$ & $128(28.6)$ & \\
\hline Asian & $7(1.0)$ & $0(0.0)$ & \\
\hline Pardo & $388(54.4)$ & $206(46.0)$ & \\
\hline Indigenous & $9(1.3)$ & $7(1.6)$ & \\
\hline BMI- $\left(\mathrm{kg} / \mathrm{m}^{2}\right)-$ median (IQR) & $20.5(18.4-23.1)$ & $19.8(17.9-22.0)$ & $<\mathbf{0 . 0 0 1}$ \\
\hline Smoking - no. (\%) & $350(54.6)$ & $224(50.0)$ & 0.140 \\
\hline Alcohol consumption - no. (\%) & $605(84.7)$ & $364(81.2)$ & 0.141 \\
\hline Illicit drug use - no. (\%) & $247(34.6)$ & $142(31.7)$ & 0.331 \\
\hline Positive smear - no. (\%) & $542(76.4)$ & $324(73.1)$ & 0.232 \\
\hline Previous diagnosis of diabetes - no. (\%) & $128(17.9)$ & $8(1.79)$ & $<\mathbf{0 . 0 0 1}$ \\
\hline Abnormal chest X-ray - no. (\%) & $686(96.1)$ & $430(96.0)$ & 0.480 \\
\hline \multicolumn{4}{|l|}{ Drug-susceptibility testing (DST) - no. (\%) } \\
\hline Rifampicin-Isoniazid resistance & $16(2.5)$ & $10(2.6)$ & 1.000 \\
\hline Rifampicin resistance & $18(2.82)$ & $13(3.37)$ & 0.756 \\
\hline Isoniazid resistance & $52(8.14)$ & $25(6.48)$ & 0.392 \\
\hline Sensitive & $628(86.5)$ & $400(87.6)$ & 1.000 \\
\hline \multicolumn{4}{|l|}{ Symptoms of TB- no. (\%) } \\
\hline Hemoptysis & $151(24.7)$ & $91(25.2)$ & 0.924 \\
\hline Cough & $613(95.5)$ & $363(92.8)$ & 0.096 \\
\hline Fever & $509(79.3)$ & $298(76.2)$ & 0.280 \\
\hline Weight Loss & $597(93.0)$ & $344(88.4)$ & 0.016 \\
\hline Fatigue & $529(82.4)$ & $311(79.5)$ & 0.289 \\
\hline Night sweats & $452(70.5)$ & $266(64.1)$ & 0.476 \\
\hline Chest pain & $415(64.7)$ & $250(64.1)$ & 0.888 \\
\hline
\end{tabular}

394

395

396

397

398

399

400

401

402

Table note: TB cases were divided in two groups based on the glycemic status in normoglycemia or dysglycemia, which included both diabetes and prediabetes. Data represent no. (\%), except for age and BMI, which is presented as median and interquartile range (IQR). Continuous variables were compared using the Mann-Whitney $U$ test and categorical variables were using the Fisher's exact test $(2 \times 2)$ or Pearson's chi-square test.

Definition of alcohol consumption: Past or current any consumption of alcohol. Definition of passive smoking: Living with someone who smokes. Definition of illicit drug use: Past or current illicit drug use (marijuana, cocaine, heroin or crack). Definition of Pardo ethnicity: mixture of European, black and Amerindian Abbreviations: TB: tuberculosis, BMI: Body Mass Index 
404 Table 2. Characteristics of TB cases by DM status in RePORT-Brazil cohort

\begin{tabular}{|c|c|c|c|c|}
\hline Characteristics & $\begin{array}{c}\text { Diabetes } \\
(n=275)\end{array}$ & $\begin{array}{c}\text { Prediabetes } \\
(n=439)\end{array}$ & $\begin{array}{l}\text { Normoglycemia } \\
(n=448)\end{array}$ & p-value \\
\hline Sex male - no. (\%) & $182(66.2)$ & $309(70.4)$ & $277(61.8)$ & 0.027 \\
\hline Age - median (IQR) & $46(36-55)$ & $36(26-47)$ & $31(23-42)$ & $<0.001$ \\
\hline HIV infection - no. (\%) & $56(20.5)$ & $97(22.2)$ & $91(20.7)$ & 0.821 \\
\hline Race/Ethnicity - no. (\%) & & & & $<\mathbf{0 . 0 0 1}$ \\
\hline White & $43(15.7)$ & $92(21.0)$ & $107(23.9)$ & \\
\hline Black & $58(21.2)$ & $116(26.4)$ & $128(28.6)$ & \\
\hline Asian & $2(0.73)$ & $5(1.14)$ & $0(0.0)$ & \\
\hline Pardo & $167(60.9)$ & $221(50.3)$ & $206(46.0)$ & \\
\hline Indigenous & $4(1.46)$ & $5(1.14)$ & $7(1.56)$ & \\
\hline BMI $\left(\mathrm{kg} / \mathrm{m}^{2}\right)$-median (IQR) & $21.6(19.1-24.4)$ & $\begin{array}{l}19.9(18.4- \\
21.8)\end{array}$ & $19.8(17.9-22.0)$ & $<0.001$ \\
\hline Smoking - no. (\%) & $158(57.6)$ & $232(52.8)$ & $224(50.0)$ & 0.150 \\
\hline Alcohol consumption - no. $(\%)$ & $242(88.0)$ & $363(82.7)$ & $364(81.2)$ & 0.053 \\
\hline Illicit drug use - no. (\%) & $77(28.0)$ & $170(38.8)$ & $142(31.7)$ & 0.007 \\
\hline Positive Smear - no. (\%) & $220(80.3)$ & $332(74.0)$ & $324(73.1)$ & 0.077 \\
\hline $\begin{array}{l}\text { Previous diagnosis of diabetes - } \\
\text { no. }(\%)\end{array}$ & $122(44.4)$ & $6(1.4)$ & $8(1.8)$ & $<0.001$ \\
\hline Abnormal chest X-ray- no. (\%) & $269(97.8)$ & $417(95.0)$ & $430(96.0)$ & 0.168 \\
\hline \multicolumn{5}{|c|}{ Drug-susceptibility testing (DST) - no. (\%) } \\
\hline Rifampicin resistance & $10(4.0)$ & $8(2.1)$ & $13(3.4)$ & 0.331 \\
\hline Isoniazid resistance & $21(8.4)$ & $31(8.0)$ & $25(6.5)$ & 0.608 \\
\hline Rifampicin-Isoniazid resistance & $8(3.2)$ & $8(2.1)$ & $10(2.6)$ & 0.666 \\
\hline Sensitive & $236(84.4)$ & $392(87.8)$ & $400(87.5)$ & 1.000 \\
\hline \multicolumn{5}{|l|}{ Symptoms of TB- no. (\%) } \\
\hline Hemoptysis & $64(27.2)$ & $87(23.1)$ & $91(25.2)$ & 0.515 \\
\hline Cough & $235(94.0)$ & $378(96.4)$ & $363(92.8)$ & 0.083 \\
\hline Fever & $196(78.4)$ & $313(79.8)$ & $298(76.2)$ & 0.466 \\
\hline Weight Loss & $235(94.0)$ & $362(92.3)$ & $344(88.4)$ & 0.033 \\
\hline Fatigue & $214(85.6)$ & $315(80.4)$ & $311(79.5)$ & 0.131 \\
\hline Night sweats & $174(69.9)$ & $278(70.9)$ & $266(68.2)$ & 0.708 \\
\hline Chest paint & $165(66.3)$ & $250(63.8)$ & $250(64.1)$ & 0.796 \\
\hline
\end{tabular}

409

410

411

412

413

414

415
Table note: Data represent no. (\%), except for age and BMI, which is presented as median and interquartile range (IQR). Continuous variables were compared using the Kruskal-Wallis test and categorical variables were using the Pearson's chi-square test. Bold values represent statistically significant.

Definition of alcohol consumption: Past or current any consumption of alcohol. Definition of smoking: Past or current cigarette smoker. Definition of passive smoking: Living with someone who smokes. Definition of illicit drug use: Past or current illicit drug use (marijuana, cocaine, heroin or crack)

Definition of persistence of symptoms: Patients who in the initial evaluation interview (baseline) reported indicated symptom and in the evaluation of visit 2 (month 2) still reported having such symptom.

Definition of Pardo ethnicity: mixture of European, black and Amerindian

Abbreviations: TB: tuberculosis, BMI: Body Mass Index 
medRxiv preprint doi: https://doi.org/10.1101/2021.10.29.21265663; this version posted October 30, 2021. The copyright holder for this preprint (which was not certified by peer review) is the author/funder, who has granted medRxiv a license to display the preprint in perpetuity.

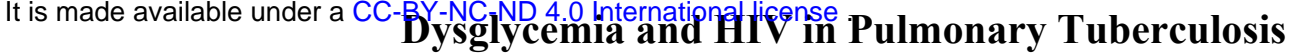

416

417 Table 3. Characteristics of TB cases by DM status in SINAN cohort

\begin{tabular}{|c|c|c|c|}
\hline Characteristics & $\begin{array}{l}\text { Diabetes } \\
(n=25765)\end{array}$ & $\begin{array}{c}\text { Normoglycemia } \\
(n=253378)\end{array}$ & p-value \\
\hline Male sex - no. (\%) & $16172(62.8)$ & $171638(67.7)$ & $<0.001$ \\
\hline Age - median (IQR) & $55.0(46.0-64.0)$ & $40.0(29.0-54.0)$ & $<0.001$ \\
\hline HIV infection - no. (\%) & $1051(4.08)$ & $31073(12.3)$ & $<0.001$ \\
\hline ART use - no. (\%) & $484(11.2)$ & $14175(27.8)$ & $<0.001$ \\
\hline Race/Ethnicity - no. (\%) & & & $<0.001$ \\
\hline White & $8243(33.8)$ & $77442(32.4)$ & \\
\hline Black/Pardo & $15750(64.6)$ & $156749(65.5)$ & \\
\hline Indigenous & $181(0.74)$ & $2997(1.25)$ & \\
\hline Asian & $210(0.86)$ & $1953(0.82)$ & \\
\hline Abnormal chest X-ray - no. (\%) & $20113(79.3)$ & $190895(76.7)$ & $<0.001$ \\
\hline Alcohol consumption - no. $(\%)$ & $3820(14.9)$ & $45548(18.0)$ & $<0.001$ \\
\hline Illicit drug use - no. (\%) & $1116(4.35)$ & $26696(10.6)$ & $<\mathbf{0 . 0 0 1}$ \\
\hline Smoking - no. (\%) & $4526(17.7)$ & $47877(19.0)$ & $<0.001$ \\
\hline Positive smear - no. (\%) & $14649(56.9)$ & $128692(50.8)$ & $<\mathbf{0 . 0 0 1}$ \\
\hline Positive culture - no. $(\%)$ & $4527(17.6)$ & $42879(16.9)$ & 0.003 \\
\hline $\begin{array}{l}\text { Drug-susceptibility testing (DST) - } \\
\% \text { ) }\end{array}$ & & & 0.116 \\
\hline Rifampicin resistance & $40(1.8)$ & $428(2.1)$ & \\
\hline Isoniazid resistance & $117(5.4)$ & $1048(5.1)$ & \\
\hline Rifampicin-Isoniazid resistance & $113(5.2)$ & $857(4.2)$ & \\
\hline Sensitive & $1906(87.6)$ & $18211(88.6)$ & \\
\hline
\end{tabular}

Table note: Data represent no. (\%), except for age, which is presented as median and interquartile range (IQR). Continuous Pearson's chi-square test. Bold values represent statistically significant Definition of Pardo ethnicity: mixture of European, black and Amerindian Abbreviations: TB: tuberculosis, ART: antiretroviral therapy 
Table 4. Characteristics of TB cases by DM status in RePORT-Brazil cohort

\begin{tabular}{|c|c|c|c|c|c|c|c|}
\hline Characteristics & $\begin{array}{c}\text { TBDM-HIV } \\
(n=56)\end{array}$ & $\begin{array}{c}\text { TBPDM-HIV } \\
(\mathbf{n}=97)\end{array}$ & $\begin{array}{c}\text { TB-HIV } \\
(n=91)\end{array}$ & $\begin{array}{c}\text { TBDM } \\
(n=217)\end{array}$ & $\begin{array}{l}\text { TBPDM } \\
(n=341)\end{array}$ & $\begin{array}{c}\text { TB } \\
(n=350)\end{array}$ & $\begin{array}{c}\text { p- } \\
\text { value }\end{array}$ \\
\hline Sex male - no. $(\%)$ & $43(76.8)$ & $75(77.3)$ & $67(73.6)$ & $137(63.1)$ & $232(68.0)$ & $209(59.7)$ & 0.002 \\
\hline Age - median (IQR) & $36(31-42)$ & $35(28-43)$ & $34(26-42)$ & $49(38-57)$ & $36(25-49)$ & $30(22-42)$ & $<0.001$ \\
\hline Race/Ethnicity - no. (\%) & & & & & & & $<0.001$ \\
\hline White & $6(10.7)$ & $26(26.8)$ & $11(12.1)$ & $37(17.1)$ & $66(19.4)$ & $95(27.1)$ & \\
\hline Black & $11(19.6)$ & $12(12.4)$ & $16(17.6)$ & $46(21.3)$ & $103(30.2)$ & $106(30.3)$ & \\
\hline Asian & $0(0.0)$ & $2(2.1)$ & $3(3.3)$ & $4(1.9)$ & $3(0.9)$ & $4(1.1)$ & \\
\hline Pardo & $39(69.6)$ & $57(58.8)$ & $61(67.0)$ & $127(58.8)$ & $164(48.1)$ & $145(41.4)$ & \\
\hline Indigenous & $0(0.0)$ & $0(0.0)$ & $0(0.0)$ & $2(0.9)$ & $5(1.5)$ & $0(0.0)$ & \\
\hline BMI- $\left(\mathrm{kg} / \mathrm{m}^{2}\right)$ - median (IQR) & $\begin{array}{c}20.5(17.5- \\
22.5)\end{array}$ & $\begin{array}{c}20.2(18.7- \\
21.8)\end{array}$ & $\begin{array}{c}19.9(17.9- \\
22.7)\end{array}$ & $\begin{array}{c}21.9(19.9- \\
25.2)\end{array}$ & $\begin{array}{c}19.8(18.1- \\
21.8)\end{array}$ & $\begin{array}{c}19.9(17.9- \\
21.8)\end{array}$ & $<0.001$ \\
\hline Smoking - no. (\%) & $36(64.3)$ & $60(61.9)$ & $56(61.5)$ & $120(55.3)$ & $171(50.1)$ & $164(46.9)$ & 0.009 \\
\hline Alcohol consumption - no. $(\%)$ & $53(94.6)$ & $91(93.8)$ & $81(89.0)$ & $187(86.2)$ & $271(79.5)$ & $276(78.9)$ & $<0.001$ \\
\hline Illicit drug use - no. (\%) & $30(53.6)$ & $47(48.5)$ & $53(58.2)$ & $47(21.7)$ & $123(36.1)$ & $85(24.3)$ & 0.023 \\
\hline Positive smear - no. $(\%)$ & $37(66.1)$ & $58(61.1)$ & $49(55.1)$ & $182(83.9)$ & $262(77.3)$ & $271(78.3)$ & $<0.001$ \\
\hline Previous diagnosis of diabetes - no. $(\%)$ & $9(16.1)$ & $22(22.9)$ & $19(21.3)$ & $41(19.2)$ & $52(15.3)$ & $55(15.8)$ & $<0.001$ \\
\hline Abnormal chest X-ray - no. (\%) & $52(92.9)$ & $81(83.5)$ & $79(86.8)$ & $215(99.1)$ & $335(98.2)$ & $344(98.3)$ & $<0.001$ \\
\hline \multicolumn{8}{|l|}{ Drug-susceptibility testing (DST) - no. (\%) } \\
\hline Rifampicin-Isoniazid resistance & $2(3.9)$ & $5(5.8)$ & $3(4.0)$ & $6(3.0)$ & $3(1.0)$ & $7(2.3)$ & 0.165 \\
\hline Rifampicin resistance & $4(7.8)$ & $5(5.8)$ & $3(4.0)$ & $6(3.0)$ & $3(1.0)$ & $10(3.3)$ & 0.057 \\
\hline Isoniazid resistance & $7(13.7)$ & $12(14.0)$ & $8(10.7)$ & $14(7.1)$ & $19(6.3)$ & $16(5.3)$ & 0.036 \\
\hline Sensitive & $45(88.2)$ & $77(89.5)$ & $69(92)$ & $177(89.4)$ & $248(82.4)$ & $265(87.5)$ & 0.115 \\
\hline \multicolumn{8}{|l|}{ Symptoms of TB- no. (\%) } \\
\hline Hemoptysis & $6(15.8)$ & $8(10.4)$ & $8(13.1)$ & $57(29.1)$ & $78(26.3)$ & $81(27.6)$ & 0.175 \\
\hline Cough & $38(74.5)$ & $78(89.7)$ & $61(81.3)$ & $196(99.0)$ & $298(98.3)$ & $295(95.8)$ & 0.004 \\
\hline Fever & $45(88.2)$ & $71(81.6)$ & $63(84.0)$ & $150(75.8)$ & $240(79.2)$ & $228(74.0)$ & 0.846 \\
\hline Weight Loss & $49(96.1)$ & $82(94.3)$ & $65(86.7)$ & $185(93.4)$ & $279(92.1)$ & $272(88.9)$ & 0.018 \\
\hline Fatigue & $48(94.1)$ & $73(83.9)$ & $68(90.7)$ & $165(83.3)$ & $240(79.2)$ & $237(76.9)$ & 0.364 \\
\hline Night sweats & $31(60.8)$ & $63(72.4)$ & $47(62.7)$ & $142(72.1)$ & $213(70.3)$ & $214(69.7)$ & 0.448 \\
\hline Chest pain & $31(60.8)$ & $47(54.0)$ & $33(44.0)$ & $134(68.0)$ & $201(66.3)$ & $212(69.1)$ & 0.108 \\
\hline
\end{tabular}

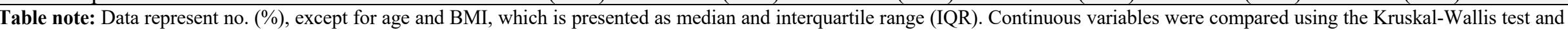
categorical variables were using the Pearson's chi-square test. Bold values represent statistically significant

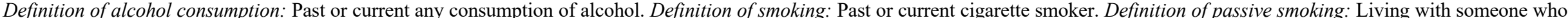

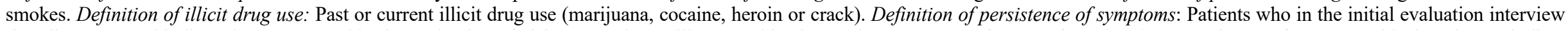

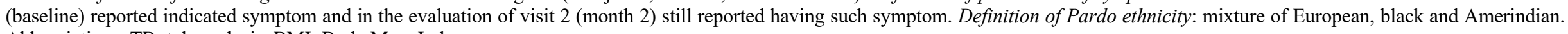
Abbreviations: TB: tuberculosis, BMI: Body Mass Index 
medRxiv preprint doi: https://doi.org/10.1101/2021.10.29.21265663; this version posted October 30, 2021. The copyright holder for this preprint (which was not certified by peer review) is the author/funder, who has granted medRxiv a license to display the preprint in perpetuity.

It is made available under a CC-BY-NC-ND 4.0 International license .

431 Table 5. Characteristics of TB cases by DM and HIV status in SINAN cohort

432

\begin{tabular}{|c|c|c|c|c|c|}
\hline Characteristics & $\begin{array}{l}\text { TBDM-HIV } \\
(n=1051)\end{array}$ & $\begin{array}{c}\text { TB-HIV } \\
\text { normoglycemia } \\
(n=31073)\end{array}$ & $\begin{array}{c}\text { TB DM } \\
(n=18591)\end{array}$ & $\begin{array}{c}\text { TB } \\
\text { normoglycemia } \\
(n=172939)\end{array}$ & $\begin{array}{c}\text { p- } \\
\text { value }\end{array}$ \\
\hline Sex male - no. (\%) & $737(70.1)$ & $22339(71.9)$ & $11684(62.8)$ & $116122(67.1)$ & $<0.001$ \\
\hline Age - median (IQR) & $49(40-57)$ & $39(31-46)$ & $55(46-63)$ & $40(28-54)$ & $<0.001$ \\
\hline ART use - no. (\%) & $468(69.1)$ & $13883(72.8)$ & - & - & $<0.001$ \\
\hline $\begin{array}{l}\text { Race/Ethnicity - no. } \\
(\%)\end{array}$ & & & & & $<0.001$ \\
\hline White & $341(34.3)$ & $9920(34.1)$ & $6220(35.2)$ & $54881(33.4)$ & \\
\hline Black/Pardo & $647(65.0)$ & $18919(65.0)$ & $11171(63.1)$ & $105690(64.4)$ & \\
\hline Indigenous & $2(0.2)$ & $112(0.4)$ & $150(0.9)$ & $2314(1.5)$ & \\
\hline Asian & $5(0.5)$ & $169(0.6)$ & $149(0.8)$ & $1357(0.8)$ & \\
\hline $\begin{array}{l}\text { Abnormal chest X- } \\
\text { ray - no. }(\%)\end{array}$ & $772(89.1)$ & $22204(87.9)$ & $14824(94.9)$ & 133615 (93.4) & $<0.001$ \\
\hline $\begin{array}{l}\text { Alcohol consumption } \\
- \text { no. }(\%)\end{array}$ & $282(28.4)$ & $6548(21.5)$ & $2703(14.9)$ & $30972(18)$ & $<0.001$ \\
\hline $\begin{array}{l}\text { Illicit drug use - no. } \\
(\%)\end{array}$ & $173(18.5)$ & $5798(19.8)$ & $767(4.4)$ & $17305(10.4)$ & $<0.001$ \\
\hline Smoking - no. (\%) & 265 (27.9) & $6374(21.6)$ & $3353(19.1)$ & 33647 (20.2) & $<0.001$ \\
\hline $\begin{array}{l}\text { Positive smear - no. } \\
(\%)\end{array}$ & $431(61.8 \%)$ & $10937(55.0)$ & $11010(77.1)$ & $93512(73.1)$ & $<0.001$ \\
\hline $\begin{array}{l}\text { Positive culture - no. } \\
(\%)\end{array}$ & $195(59.3 \%)$ & $5266(58.3)$ & $3667(65.4)$ & $32453(64.3)$ & $<0.001$ \\
\hline $\begin{array}{l}\text { Drug-susceptibility } \\
\text { testing (DST) -no. } \\
(\%)\end{array}$ & & & & & $<0.001$ \\
\hline $\begin{array}{l}\text { Rifampicin } \\
\text { resistance }\end{array}$ & $4(4.0)$ & $91(3.4)$ & $31(1.7)$ & $290(1.8)$ & \\
\hline Isoniazid resistance & $3(3.0)$ & $137(5.1)$ & $95(5.2)$ & $791(5.0)$ & \\
\hline $\begin{array}{l}\text { Rifampicin- } \\
\text { Isoniazid resistance }\end{array}$ & $8(8.1)$ & $119(4.4)$ & $92(5.1)$ & $644(4.1)$ & \\
\hline Sensitive & $84(84.8)$ & $2360(87.2)$ & $1602(88.0)$ & $14089(89.1)$ & \\
\hline
\end{tabular}

433

434

435

436

437

438

Table note: Data represent no. (\%), except for age, which is presented as median and interquartile range (IQR). Continuous variables were compared using the Mann-Whitney $U$ test and categorical variables were using the Fisher's exact test (ART use) or Pearson's chi-square test. Bold values represent statistically significant.

Definition of Pardo ethnicity: mixture of European, black and Amerindian

Abbreviations: TB: tuberculosis, ART: antiretroviral therapy 


\section{Conflict of Interest}

441 The authors declare that the research was conducted in the absence of any commercial or financial relationships that could be construed as a potential conflict of interest.

\section{$7 \quad$ Author Contributions}

444 Conceptualization, T.R.S., M.C.F., M.C.S., V.C.R., and B.B.A.; Data curation, M.B.A., M.A-P., A.T.L.Q., M.M.S.R., and B.B.A.; Investigation, M.B.A., M.A-P., B.B-D., C.S., J.P.M.P.,E.V.N., B.M.F.N., M.S.R.,A.B.S.,A.B., J.G.O., A.S.R.M., R.S.G., M.C.F., B.D., J.R.L.S., A.L.K., S.C., V.C.R., T.R.S., M.C.S., and B.B.A.; Formal analysis, M.B.A., M.A-P., B.B-D. and B.B.A.; Funding acquisition, B.D., J.R.L.S., A.L.K., S.C., V.C.R., T.R.S., M.C.S., M.C.F., and B.B.A.; Methodology, M.B.A., M.A-P., B.B-D., and B.B.A.; Project administration, M.C.F., T.R.S., and B.B.A.; Resources, M.B.A., M.A-P., B.B-D., T.R.S., and B.B.A.; Software, M.B.A., M.A-P., A.T.L.Q., M.M.S.R., M.C.F., T.R.S., and B.B.A.; Supervision, T.R.S., and B.B.A.; Writing-original draft, M.B.A., M.AP., B.B-D., J.P.M.P., C.S., E.V.N. and B.B.A.; Writing-review and editing, all authors. All authors have read and agreed to the submitted version of the manuscript.

\section{$8 \quad$ Funding}

The study was supported in part by the intramural research program of FIOCRUZ (B.B.A.), Fogarty International Center and National Institute of Child Health \& Human Development of the National Institutes of Health under (Award Number D43 TW009763 through a research scholarship awarded to M.B.A.) and by the NIH (U01AI069923). B.B.A., J.R.L.S., A.L.K., V.C.R. are senior scientists from the Conselho Nacional de Desenvolvimento Científico e Tecnológico (CNPq), Brazil. M.B.A. received a research fellowship from the Fundação de Amparo à Pesquisa do Estado da Bahia (FAPESB), Brazil. M.A-P. and B.B-D. received a fellowship from Coordenação de Aperfeiçoamento de Pessoal de Nível Superior (Finance code: 001).

\section{$9 \quad$ Acknowledgments}

The authors thank the study participants. We also thank the teams of clinical and laboratory platforms of RePORT-Brazil. A special thanks to Elze Leite (FIOCRUZ, Salvador, Brazil), Eduardo Gama (FIOCRUZ, Rio de Janeiro, Brazil), Elcimar Junior (FMT-HVD, Manaus, Brazil), and Hilary Vansell (VUMC, Nashville, USA) for administrative and logistical support.

\section{Contribution to the Field Statement}

Persons with dysglycemia (i.e., diabetes or prediabetes) have increased odds of becoming infected with tuberculosis and of progressing from latent to active disease. Moreover, people with tuberculosisdiabetes comorbidity exhibit increased risk of unfavorable outcomes and mortality during antituberculosis therapy. This context is complicated by the presence of another known epidemic that is HIV. The comorbidity of tuberculosis-HIV accelerates immune deterioration and represents the highest 
interaction between diabetes, tuberculosis, and HIV. In the present study, we examined two large cohorts of persons with pulmonary tuberculosis in Brazil to demonstrate that patients with tuberculosisdysglycemia present a distinct clinical profile, being mainly older and presenting a greater severity of symptoms than individuals with normoglycemic tuberculosis. Moreover, our results indicate that the presence of HIV does not substantially affect the clinical presentation of people with tuberculosisdysglycemia, although it is associated with a more frequent use of recreational drugs and negative sputum samples during tuberculosis screening. The findings provide robust evidence to support bidirectional screening of tuberculosis and diabetes. Future studies are warranted to investigate whether HIV impacts clinical presentation and outcomes of persons with tuberculosis-diabetes comorbidity in other highly endemic regions.

\section{References}

Abaye, G.E., Abebe, T., Worku, A., Tolessa, D., Ameni, G., and Mihret, A. (2017). Detection of Mycobacterium tuberculosis from the stool of HIV sero-positive individuals suspected of pulmonary tuberculosis. PLoS One 12, e0177529.

Abdelbary, B.E., Garcia-Viveros, M., Ramirez-Oropesa, H., Rahbar, M.H., and Restrepo, B.I. (2016). Tuberculosis-diabetes epidemiology in the border and non-border regions of Tamaulipas, Mexico. Tuberculosis (Edinburgh, Scotland) 101S, S124-S134.

Abdul-Ghani, M.A., Tripathy, D., and Defronzo, R.A. (2006). Contributions of beta-cell dysfunction and insulin resistance to the pathogenesis of impaired glucose tolerance and impaired fasting glucose. Diabetes Care 29, 1130-1139.

Abreu, R.G., Rolim, L.S., Sousa, A.I.A., and Oliveira, M.R.F. (2020). Tuberculosis and diabetes: association with sociodemographic characteristics and diagnosis and treatment of tuberculosis. Brazil, 2007-2011. Rev Bras Epidemiol 23, e200009.

Almeida-Junior, J.L., Gil-Santana, L., Oliveira, C.a.M., Castro, S., Cafezeiro, A.S., Daltro, C., Netto, E.M., Kornfeld, H., and Andrade, B.B. (2016). Glucose Metabolism Disorder Is Associated with Pulmonary Tuberculosis in Individuals with Respiratory Symptoms from Brazil. PloS One 11, e0153590.

American Diabetes, A. (2021). Classification and Diagnosis of Diabetes: Standards of Medical Care in Diabetes-2021. Diabetes Care 44 Suppl 1, S15-S33.

Arriaga, M.B., Amorim, G., Queiroz, A.T.L., Rodrigues, M.M.S., Araújo-Pereira, M., Nogueira, B.M.F., Souza, A.B., Rocha, M.S., Benjamin, A., Moreira, A.S.R., De Oliveira, J.G., Figueiredo, M.C., Turner, M.M., Alves, K., Durovni, B., Lapa-E-Silva, J.R., Kritski, A.L., Cavalcante, S., Rolla, V.C., Cordeiro-Santos, M., Sterling, T.R., Andrade, B.B., and Consortium, R.B. (2021). Novel stepwise approach to assess representativeness of a large multicenter observational cohort of tuberculosis patients: The example of RePORT Brazil. International journal of infectious diseases: IJID: official publication of the International Society for Infectious Diseases 103, 110-118.

Bailey, S.L., and Ayles, H. (2017). Association between diabetes mellitus and active tuberculosis in Africa and the effect of HIV. Trop Med Int Health 22, 261-268.

Beraldo, A.A., Andrade, R.L.D.P., Pinto, É.S.G., Da Silva-Sobrinho, R.A., Saita, N.M., Monroe, A.A., and Villa, T.C.S. (2021). Tuberculose e diabetes mellitus: perfil sociodemográfico e clínico em municípios brasileiros. Revista Gaúcha de Enfermagem 42. 
medRxiv preprint doi: https://doi.org/10.1101/2021.10.29.21265663; this version posted October 30, 2021. The copyright holder for this preprint (which was not certified by peer review) is the author/funder, who has granted medRxiv a license to display the preprint in perpetuity. It is made available under a CC-BY-NC-ND 4.0 nnternatipn Hivense Pulmonary Tuberculosis

Bhatta, D.N., Subedi, A., and Sharma, N. (2018). Tobacco smoking and alcohol drinking among HIV infected people using antiretroviral therapy. Tob Induc Dis 16, 16.

Calderon, R.I., Arriaga, M.B., Lopez, K., Barreda, N.N., Sanabria, O.M., Froes Neto, J.F., Araujo, D.N., Lecca, L., and Andrade, B.B. (2019). High prevalence and heterogeneity of Dysglycemia in patients with tuberculosis from Peru: a prospective cohort study. BMC Infect Dis 19, 799.

Duro, M., Rebelo, I., Barreira, S., Sarmento-Castro, R., Medeiros, R., and Almeida, C. (2015). Glycaemic profile changes by highly active antiretroviral therapy in human immunodeficiency virus-infected patients. Int J STD AIDS 26, 796-802.

Evangelista, M.D.S.N., Maia, R., Toledo, J.P., Abreu, R.G.D., and Barreira, D. (2020). Tuberculosis associated with diabetes mellitus by age group in Brazil: a retrospective cohort study, 20072014. Brazilian Journal of Infectious Diseases 24, 130-136.

Geldmacher, C., Ngwenyama, N., Schuetz, A., Petrovas, C., Reither, K., Heeregrave, E.J., Casazza, J.P., Ambrozak, D.R., Louder, M., Ampofo, W., Pollakis, G., Hill, B., Sanga, E., Saathoff, E., Maboko, L., Roederer, M., Paxton, W.A., Hoelscher, M., and Koup, R.A. (2010). Preferential infection and depletion of Mycobacterium tuberculosis-specific CD4 T cells after HIV-1 infection. J Exp Med 207, 2869-2881.

Gil-Santana, L., Almeida-Junior, J.L., Oliveira, C.a.M., Hickson, L.S., Daltro, C., Castro, S., Kornfeld, H., Netto, E.M., and Andrade, B.B. (2016). Diabetes Is Associated with Worse Clinical Presentation in Tuberculosis Patients from Brazil: A Retrospective Cohort Study. PloS One 11, e0146876.

Girardi, E., Sañé Schepisi, M., Goletti, D., Bates, M., Mwaba, P., Yeboah-Manu, D., Ntoumi, F., Palmieri, F., Maeurer, M., Zumla, A., and Ippolito, G. (2017). The global dynamics of diabetes and tuberculosis: the impact of migration and policy implications. International journal of infectious diseases: IJID: official publication of the International Society for Infectious Diseases 56, 45-53.

Glesby, M.J., Hoover, D.R., Shi, Q., Danoff, A., Howard, A., Tien, P., Merenstein, D., Cohen, M., Golub, E., Dehovitz, J., Nowicki, M., and Anastos, K. (2010). Glycated haemoglobin in diabetic women with and without HIV infection: data from the Women's Interagency HIV Study. Antivir Ther 15, 571-577.

Goncalves, A.N.A., Lever, M., Russo, P.S.T., Gomes-Correia, B., Urbanski, A.H., Pollara, G., Noursadeghi, M., Maracaja-Coutinho, V., and Nakaya, H.I. (2019). Assessing the Impact of Sample Heterogeneity on Transcriptome Analysis of Human Diseases Using MDP Webtool. Front Genet 10, 971.

Hamilton, C.D., Swaminathan, S., Christopher, D.J., Ellner, J., Gupta, A., Sterling, T.R., Rolla, V., Srinivasan, S., Karyana, M., Siddiqui, S., Stoszek, S.K., and Kim, P. (2015). RePORT International: Advancing Tuberculosis Biomarker Research Through Global Collaboration. Clin Infect Dis 61Suppl 3, S155-159.

Hayashi, S., and Chandramohan, D. (2018). Risk of active tuberculosis among people with diabetes mellitus: systematic review and meta-analysis. Tropical medicine \& international health: TM \& IH 23, 1058-1070.

He, X., Eddy, J.J., Jacobson, K.R., Henderson, A.J., and Agosto, L.M. (2020). Enhanced Human Immunodeficiency Virus-1 Replication in CD4+ T Cells Derived From Individuals With Latent Mycobacterium tuberculosis Infection. J Infect Dis 222, 1550-1560. 
medRxiv preprint doi: https://doi.org/10.1101/2021.10.29.21265663; this version posted October 30, 2021. The copyright holder for this preprint (which was not certified by peer review) is the author/funder, who has granted medRxiv a license to display the preprint in perpetuity. It is made available under a CC-BY-NC-ND 4 . nnternatipnallivense Pulmonary Tuberculosis

563

564

565

566

567

568

569

570

571

572

573

574

575

576

577

578

579

580

581

582

583

584

585

586

587

588

589

590

591

592

593

594

595

596

597

598

599

600

601

602

603

604

Hensel, R.L., Kempker, R.R., Tapia, J., Oladele, A., Blumberg, H.M., and Magee, M.J. (2016). Increased risk of latent tuberculous infection among persons with pre-diabetes and diabetes mellitus. The international journal of tuberculosis and lung disease : the official journal of the International Union against Tuberculosis and Lung Disease 20, 71-78.

International Diabetes Federation (2019). Diabetes Atlas.

Jeon, C.Y., and Murray, M.B. (2008). Diabetes mellitus increases the risk of active tuberculosis: a systematic review of 13 observational studies. PLoS medicine 5, e152.

Julius, H., Basu, D., Ricci, E., Wing, J., Basu, J.K., Pocaterra, D., and Bonfanti, P. (2011). The burden of metabolic diseases amongst HIV positive patients on HAART attending The Johannesburg Hospital. Current HIV research 9, 247-252.

Khalil, N.H., and Ramadan, R.A. (2016). Study of risk factors for pulmonary tuberculosis among diabetes mellitus patients. Egyptian Journal of Chest Diseases and Tuberculosis 65, 817-823.

Ministério Da Saúde Do Brasil, and Secretaria De Vigilância Em Saúde (2013). "Manual de Recomendações para o Controle da Tuberculose no Brasil".).

Ministério Da Saúde Do Brasil, and Secretaria De Vigilância Em Saúde (2020). Sistema de Informação de Agravos de Notificação [Online]. Available: http://portalsinan.saude.gov.br/ [Accessed 0814-2020)].

Moir, S., Chun, T.W., and Fauci, A.S. (2011). Pathogenic mechanisms of HIV disease. Аnпи Rev Pathol 6, 223-248.

Noubiap, J.J., Nansseu, J.R., Nyaga, U.F., Nkeck, J.R., Endomba, F.T., Kaze, A.D., Agbor, V.N., and Bigna, J.J. (2019). Global prevalence of diabetes in active tuberculosis: a systematic review and meta-analysis of data from 2.3 million patients with tuberculosis. The Lancet Global Health 7, e448-e460.

Oni, T., Berkowitz, N., Kubjane, M., Goliath, R., Levitt, N.S., and Wilkinson, R.J. (2017). Trilateral overlap of tuberculosis, diabetes and HIV-1 in a high-burden African setting: implications for TB control. Eur Respir J 50.

Pelissari, D.M., and Diaz-Quijano, F.A. (2018). Impact of alcohol disorder and the use of illicit drugs on tuberculosis treatment outcomes: a retrospective cohort study. Archives of Public Health 76, 45.

Prada-Medina, C.A., Fukutani, K.F., Pavan Kumar, N., Gil-Santana, L., Babu, S., Lichtenstein, F., West, K., Sivakumar, S., Menon, P.A., Viswanathan, V., Andrade, B.B., Nakaya, H.I., and Kornfeld, H. (2017). Systems Immunology of Diabetes-Tuberculosis Comorbidity Reveals Signatures of Disease Complications. Sci Rep 7, 1999.

Santos, M.L., Coeli, C.M., Batista, J.D.L., Braga, M.C., and Albuquerque, M. (2018). Factors associated with underreporting of tuberculosis based on data from Sinan Aids and Sinan TB. Rev Bras Epidemiol 21, e180019.

Singla, R., Khan, N., Al-Sharif, N., Ai-Sayegh, M.O., Shaikh, M.A., and Osman, M.M. (2006). Influence of diabetes on manifestations and treatment outcome of pulmonary TB patients. The International Journal of Tuberculosis and Lung Disease: The Official Journal of the International Union Against Tuberculosis and Lung Disease 10, 74-79.

World Health Organization (2020). "Global Tuberculosis Report 2020".).

World Health Organization (2021). "Global Tuberculosis Report 2021".). 
medRxiv preprint doi: https://doi.org/10.1101/2021.10.29.21265663; this version posted October 30, 2021. The copyright holder for this preprint (which was not certified by peer review) is the author/funder, who has granted medRxiv a license to display the preprint in perpetuity. It is made available under a CC-BY-NC-ND 4.0 internatipnaltirense Pulmonary Tuberculosis

605

606

607

608

609

610

611

612

613

614

615
Yorke, E., Boima, V., Dey, I.D., Amissah-Arthur, M.-B., Ganu, V., Amaning-Kwarteng, E., Tetteh, J., and Charles Mate-Kole, C. (2021). Transient Impact of Dysglycemia on Sputum Conversion among Smear-Positive Tuberculosis Patients in a Tertiary Care Facility in Ghana. Clinical Medicine Insights: Circulatory, Respiratory and Pulmonary Medicine 15, 11795484211039830 .

Yu, M., Xu, C.-X., Zhu, H.-H., Hu, R.-Y., Zhang, J., Wang, H., He, Q.-F., Su, D.-T., Zhao, M., Wang, L.-X., Gong, W.-W., Pan, J., Fang, L., and Ye, Z. (2014). Associations of cigarette smoking and alcohol consumption with metabolic syndrome in a male Chinese population: a crosssectional study. Journal of Epidemiology 24, 361-369. 
medRxiv preprint doi: https://doi.org/10.1101/2021.10.29.21265663; this version posted October 30, 2021. The copyright holder for this preprint (which was not certified by peer review) is the author/funder, who has granted medRxiv a license to display the preprint in perpetuity.

It is made available under a CC-BY-NC-ND 4.0 internatipnaltirense Pulmonary Tuberculosis

616

61712 Figure Legends
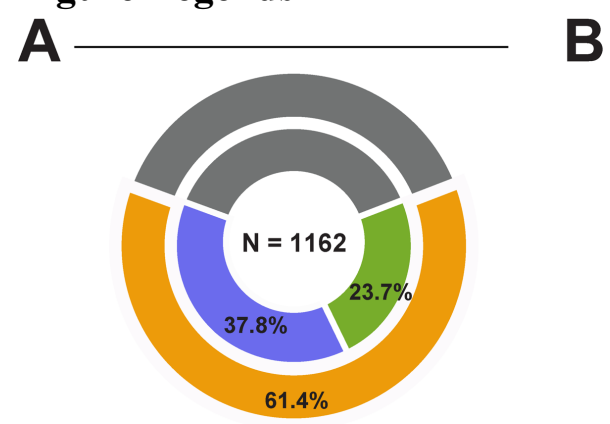

Normoglycemia Dysglycemia

Prediabetes Diabetes
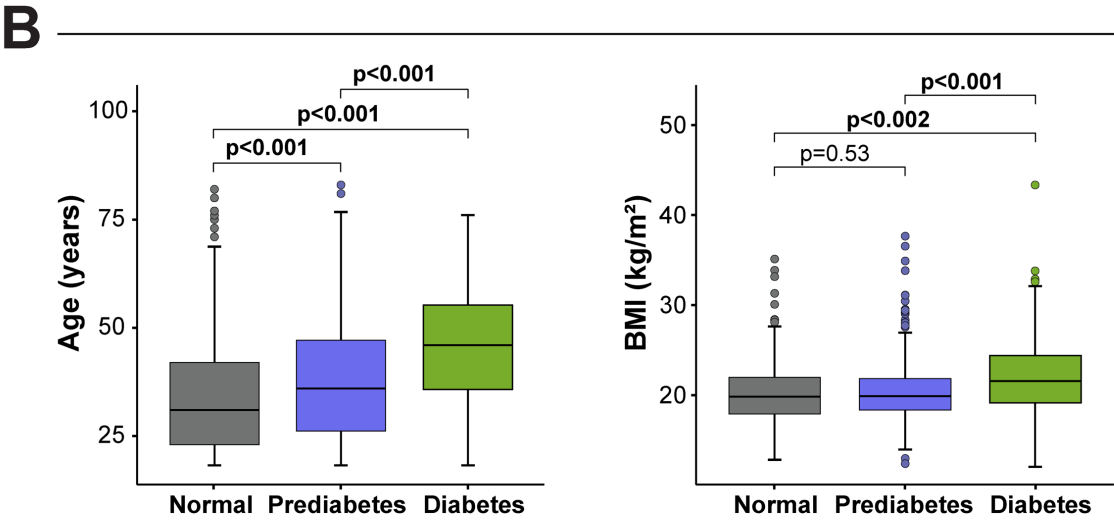

C

618

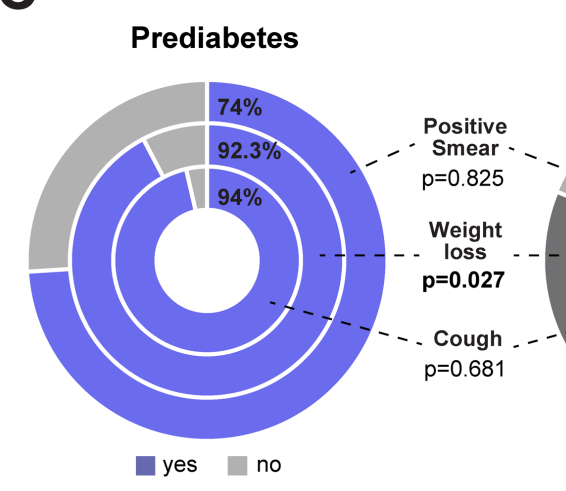

Normoglycemia

Diabetes

619 Figure 1. Characteristics of patients with pulmonary TB according to dysglycemia status in

620 RePORT-Brazil cohort. (A) Among all the individuals with active pulmonary TB ( $\mathrm{n}=1162), 61.4 \%$

621

622 had dysglycemia: $37.8 \%$ pre-DM and 23.7\% DM. (B) Comparison of Age and BMI between groups were performed using Mann-Whitney $U$ test. (C) Characteristics of the pulmonary TB cases stratified according to the presence of diabetes or prediabetes were compared with those from patients with

624 normoglycemia using the Fisher's exact test (additional comparisons are displayed in Table 2). (D) Frequency of new cases of DM diagnosis. The statistical analyzes were carried out only with the available data, omitting the cases with missing information. Abbreviations: TB: tuberculosis, BMI: 

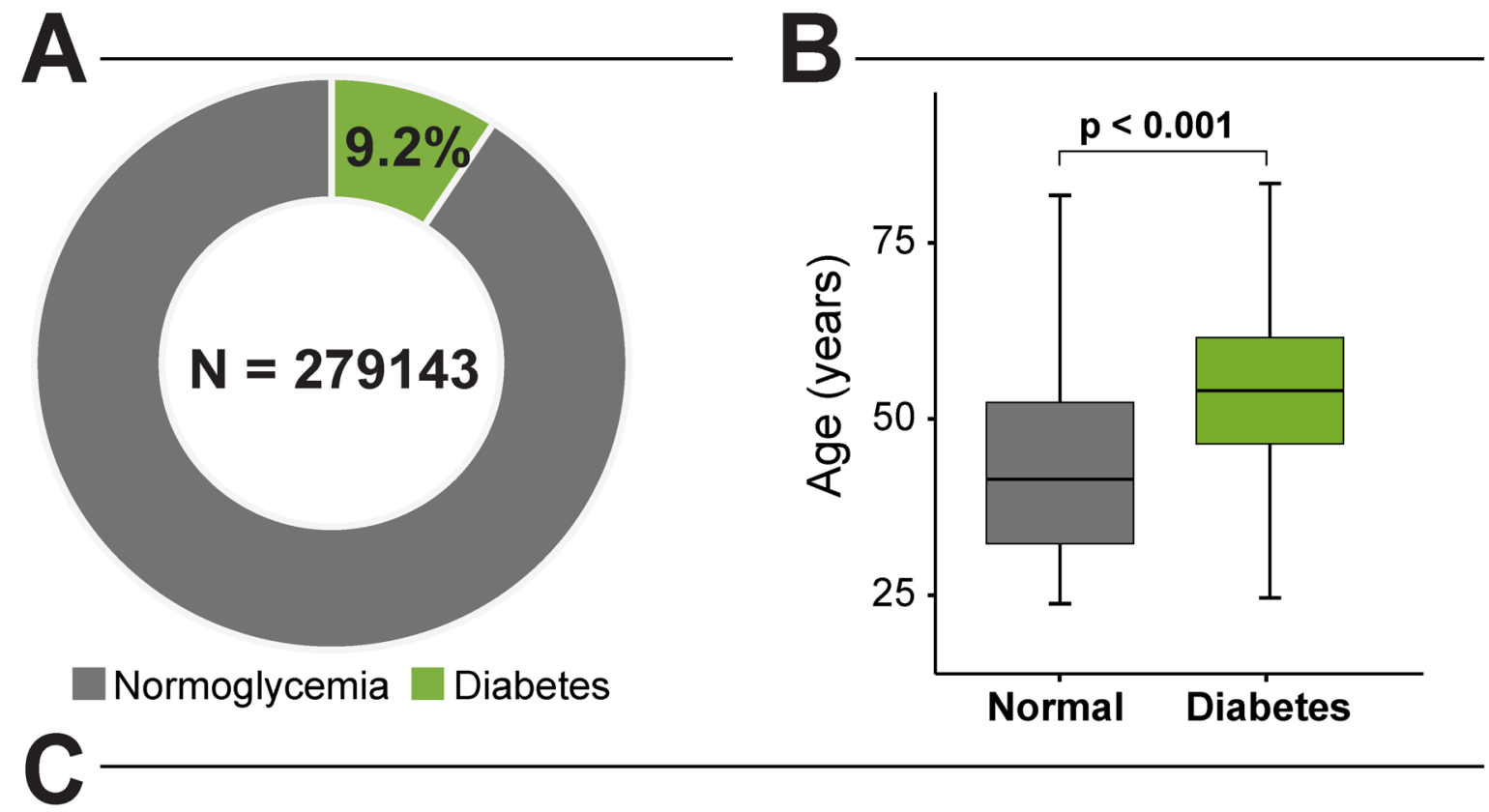

Normoglycemia Diabetes

\section{Normoglycemia}

\section{Diabetes}

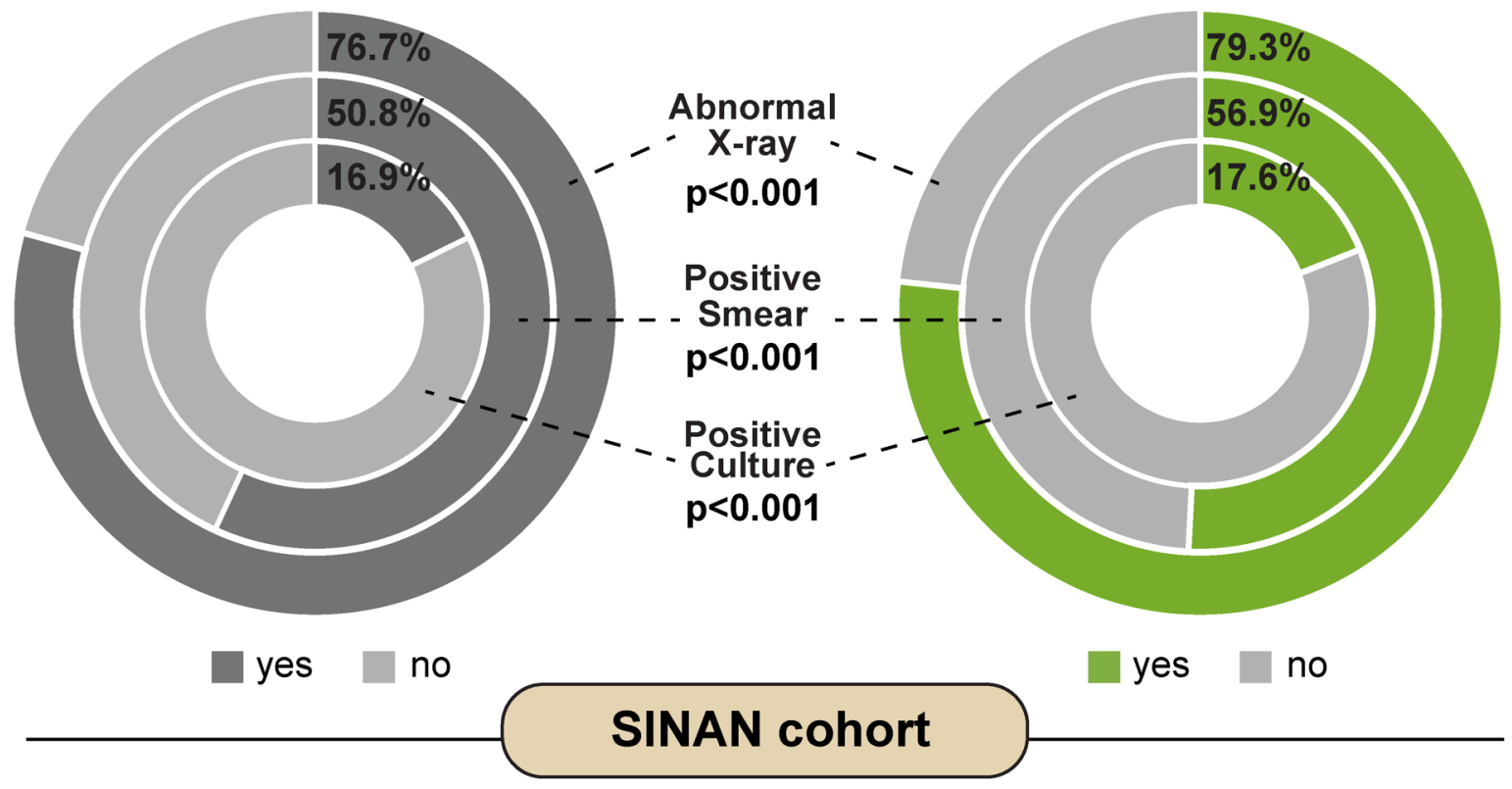
cohort. (A) Among all the individuals with active pulmonary TB ( $\mathrm{n}=287581)$ between 2015 and 2019 in Brazil, 9.2\% had DM. (B) Comparison age between groups were performed using Mann-Whitney $U$ test. (C) Characteristics of the pulmonary TB cases stratified according to the presence of diabetes were compared with those from patients with normoglycemia using the Fisher's exact test (additional comparisons are displayed in Table 2). (Additional comparisons are displayed in Table 3). The statistical analyzes were carried out only with the available data, omitting the cases with missing information. 


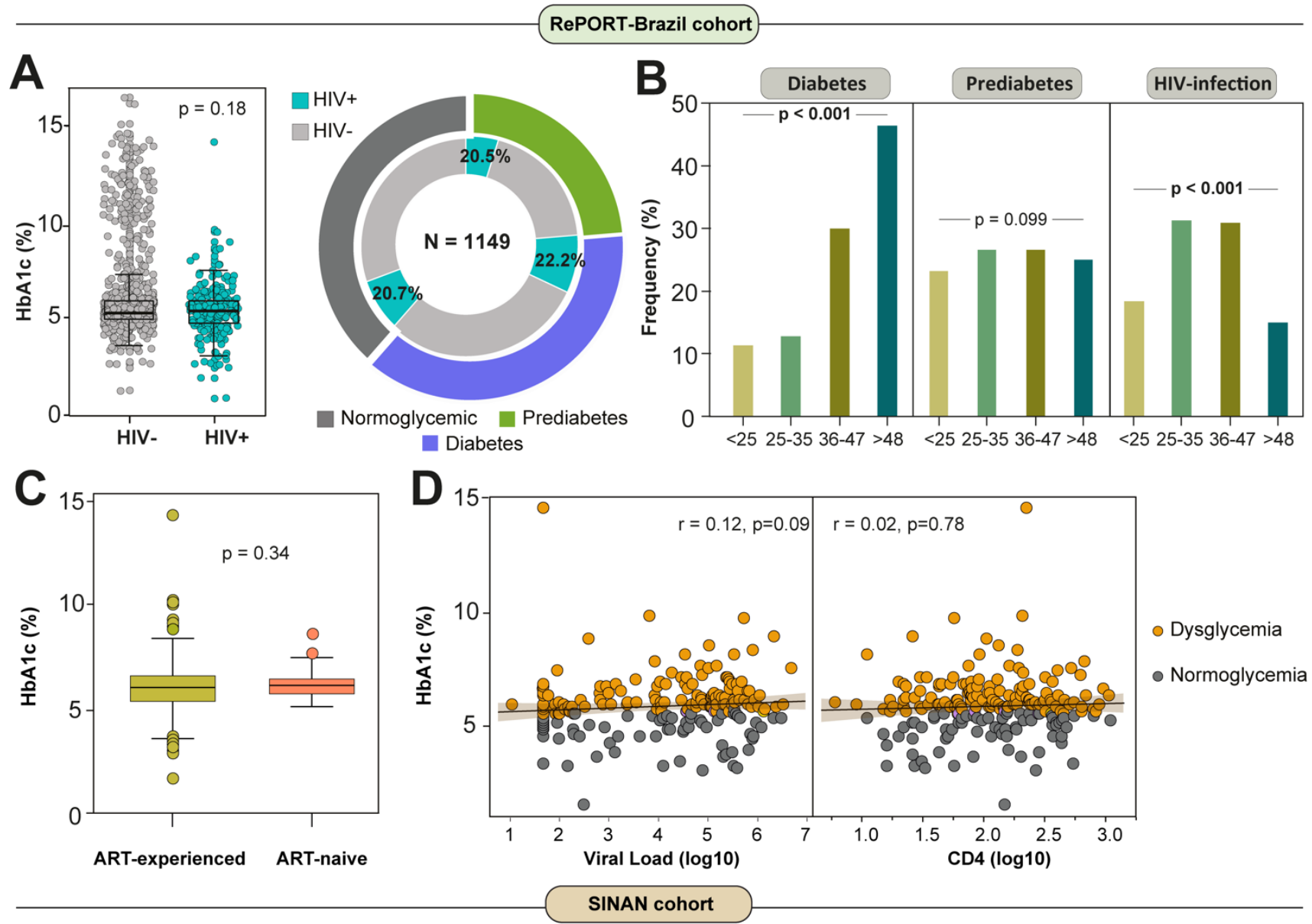

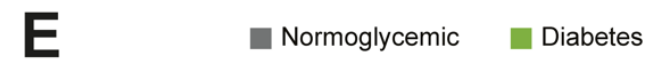

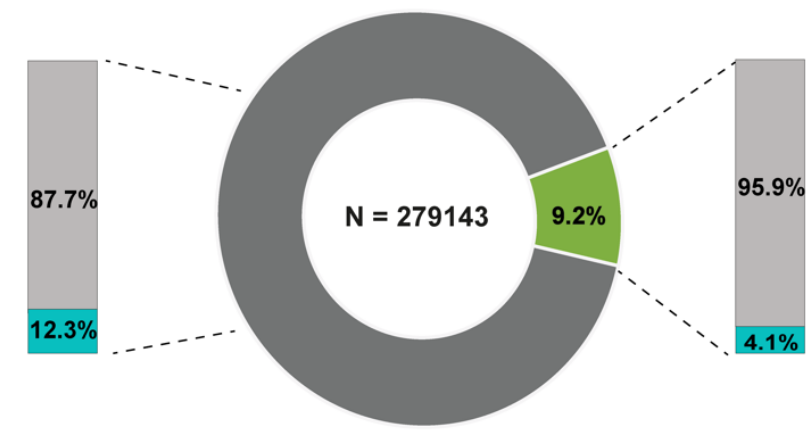

$\mathbf{F}$

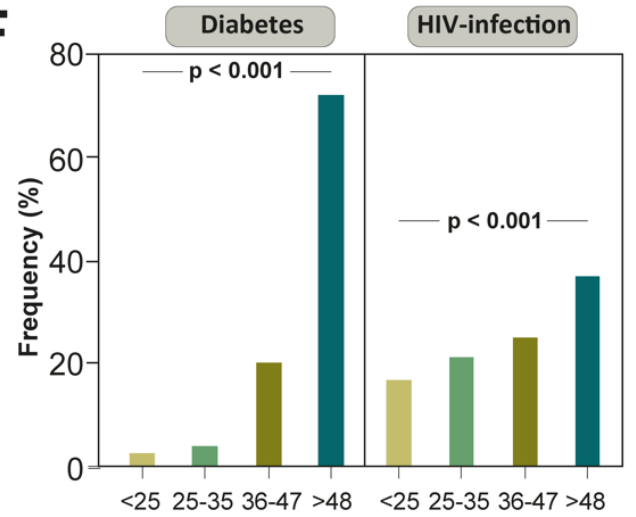

639

640

641

642

643

644

645

646

647

648

649

650

651

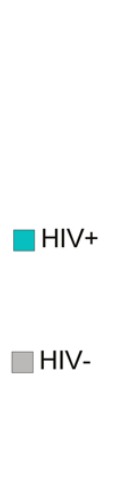

Figure 3. HIV infection among dysglycemic patients with active tuberculosis in RePORT-Brazil and SINAN cohorts. (A) Left panel: Scatter plot comparing distribution of HbAlc levels between subgroups of pulmonary TB cases per HIV infection status. Data were compared using the MannWhitney $U$ test. Left panel: Total frequency of HIV infection among diabetic TB patients was $20.5 \%$, among prediabetics was $22 \cdot 2 \%$ and among normoglycemic patients was $20.7 \%$ (chi-square test $\mathrm{p}>0.05$ ). (B) Frequency of individuals with diagnosis of diabetes, prediabetes and HIV infection in the indicated age category (in years) among pulmonary TB patients is shown. Data were compared using the Pearson's chi-square test. (C) Box plot comparing distribution of HbA1c levels between subgroups of pulmonary TB cases per ART-experience and ART-naive status. Data were compared using the Mann-Whitney $U$ test. (D) Spearman correlation between HbA1c and viral load (log10) levels (Left panel) and CD4 (log10) levels (Right panel) at baseline in pulmonary TB patients grouped according to the dysglycemic status. Line and shaded area represent linear curve fit with $95 \%$ confidence interval. 
medRxiv preprint doi: https://doi.org/10.1101/2021.10.29.21265663; this version posted October 30, 2021. The copyright holder for this preprint (which was not certified by peer review) is the author/funder, who has granted medRxiv a license to display the preprint in perpetuity.

It is made available under a CC-BY-NC-ND 4.0 internatipnałtifense Pulmonary Tuberculosis

652 (E) Total frequency of HIV infection among diabetic TB patients was $4.1 \%$ and among normoglycemic patients was $12.3 \%$ (chi-square test $\mathrm{p}>0.05$ ). The statistical analyzes were carried out only with the available data, omitting the cases with missing information (14 patients were removed due to lack in HIV status). (F) Frequency of individuals with diagnosis of diabetes and HIV infection in the indicated age category (in years) among pulmonary TB patients is shown. Data were compared using the Pearson's chi-square test. Abbreviations: ART: antiretroviral therapy.

A

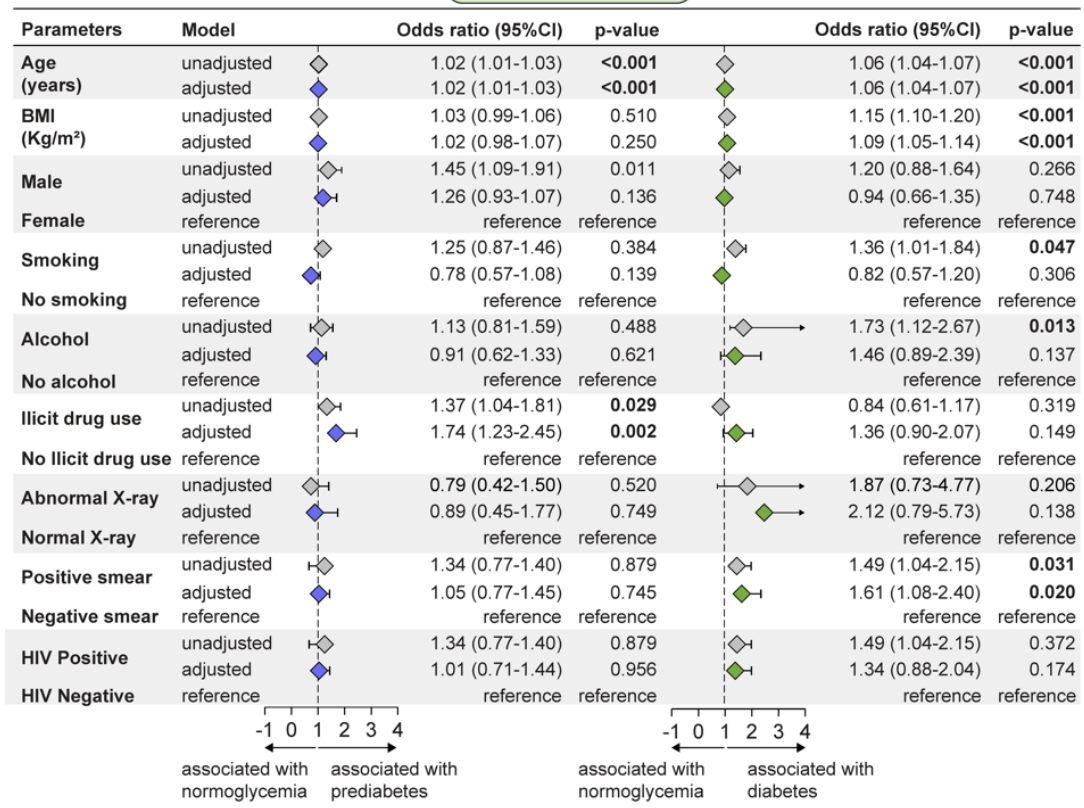

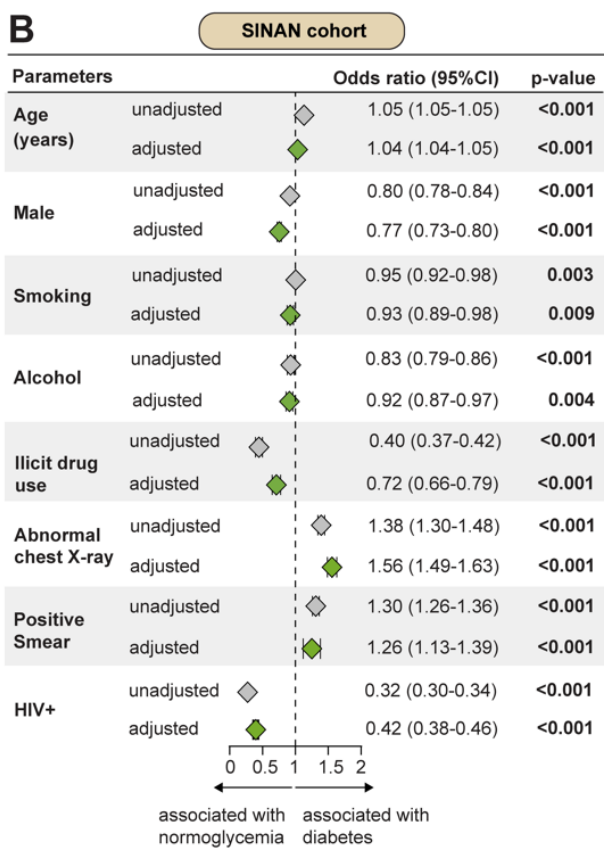

661 Figure 4. Factors associated with dysglycemia in patients with active pulmonary tuberculosis in

662 RePORT-Brazil and SINAN cohorts. (A) A multinomial logistic regression analyses were used to 663 test association between indicated characteristics of pulmonary TB patients and presence of prediabetes 664 (left panel) or diabetes (right panel). Variables included in the adjusted model exhibited univariate p665 values $\leq 0 \cdot 2$ (See Table 2 for details). (B) Binomial logistic regression to test association between 666 indicated characteristics of TB patients and presence of diabetes. Only variables with significant p667 value in the adjusted model are shown. Variables included in the adjusted model exhibited univariate 668 p-values $\leq 0.2$ (See Table 3 for details). Abbreviations: BMI: Body Mass Index. 

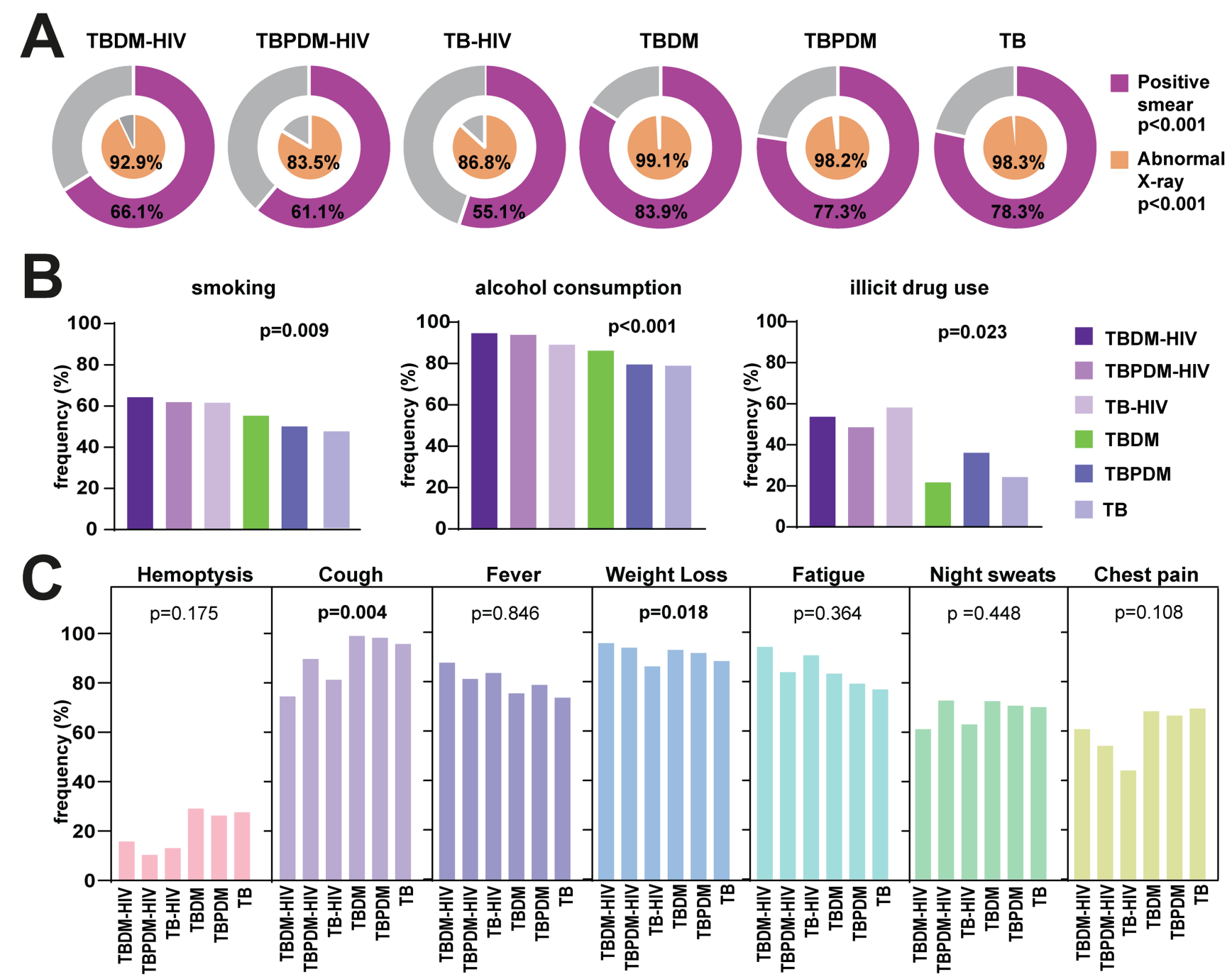

671 Figure 5: Clinical Characteristics of people with TB according glycemic and HIV status in the 672 RePORT-Brazil cohort. (A) Proportion of positive smears and abnormal X-rays in each study group.

673 (B) Frequency of TB cases according glycemic and HIV status regarding smoking habit, alcohol 674 consumption and illicit drug use (smoking, alcohol, and illicit drug: in the past or at the time of 675 evaluation before anti-TB treatment). (C) Frequency of TB classical symptoms in each study group. 676 The data were compared between the groups using the Pearson's chi-square test. Comparisons with 677 significant p-values are displayed in bold. Abbreviations: TB: tuberculosis, DM: diabetes, PDM: 678 prediabetes. 


\section{A}

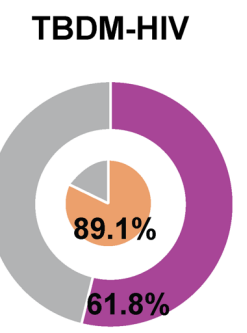

B

TBDM-HIV

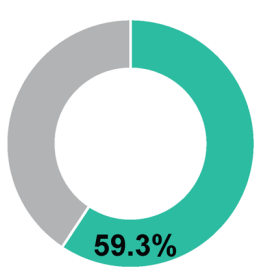

smoking

680
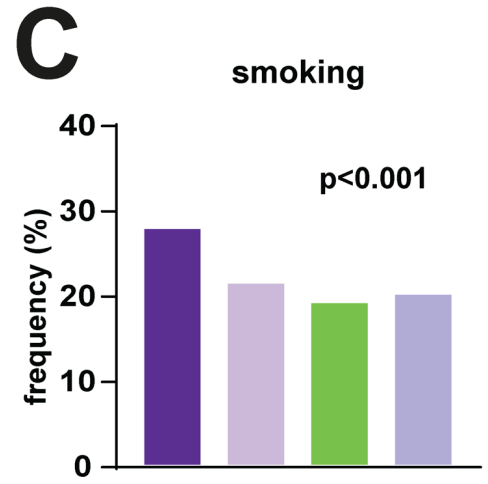

TB-HIV

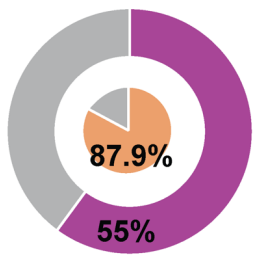

TB-HIV

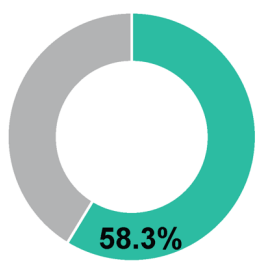

alcohol consumption

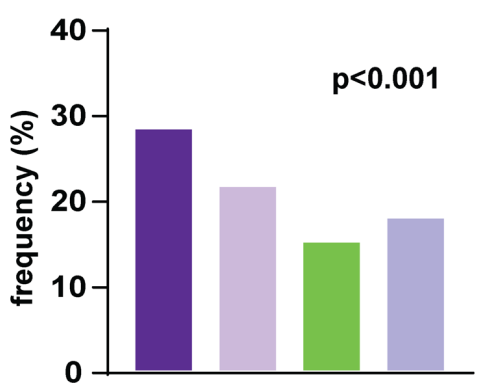

TBDM

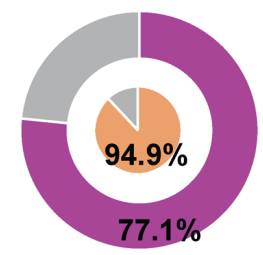

TBDM

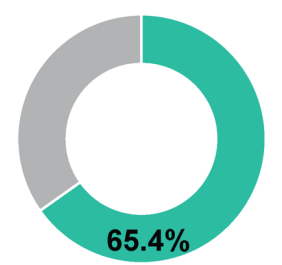

TB

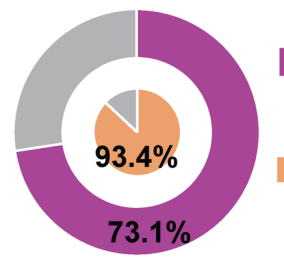

TB

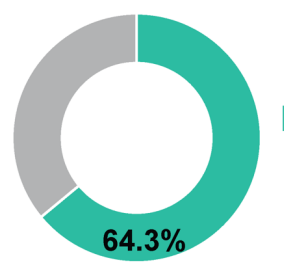

Positive culture $\mathrm{p}<0.001$
Positive smear $\mathrm{p}<0.001$

Abnormal X-ray $p<0.001$

illicit drug use

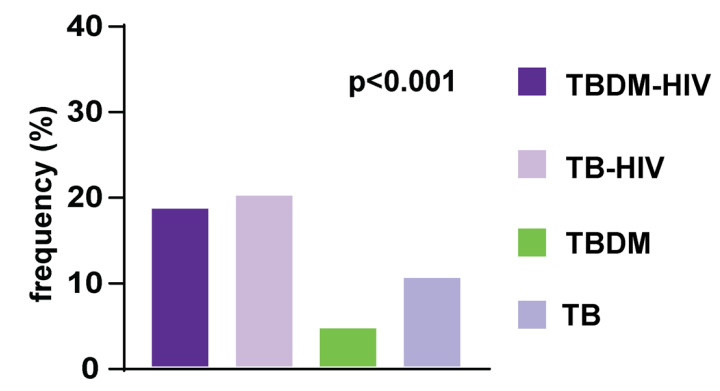

681 Figure 6: Clinical Characteristics of people with TB according glycemic and HIV status of the 682 SINAN cohort. (A) Proportion of positive smears and abnormal X-rays in each study group. (B) 683 Frequency of positive cultures. (C) TB cases according glycemic and HIV status regarding smoking 684 habit, alcohol consumption and illicit drug use (smoking, alcohol, and illicit drug: in the past or at the 685 time of evaluation before anti-TB treatment). The data were compared between the groups using the 686 Pearson's chi-square test. Comparisons with significant p-values are displayed in bold. Abbreviations: 687 TB: tuberculosis, DM: diabetes, PDM: prediabetes. 